\title{
NACJONALIZACJA W EUROPIE ZACHODNIEJ W DRUGIEJ POŁOWIE LAT 40. XX WIEKU
}

$\mathrm{W}$ artykule postawiłem sobie za cel:

- odróżnienie nacjonalizacji od innych form powiększania sektora państwowego w gospodarce;

- przedstawienie zarysu historii nacjonalizacji i wstępną próbę typologii zjawiska;

- analizę kluczowych, w moim przekonaniu, politycznych uwarunkowań nacjonalizacji zachodnioeuropejskiej z pierwszych lat po II wojnie światowej; przeprowadzono ją wówczas w trzech krajach: Austrii (niemającej jeszcze statusu państwowego), Francji i Wielkiej Brytanii;

- porównanie okoliczności i przebiegu owych trzech przypadków nacjonalizacji.

\section{Uwagi terminologiczne}

Termin „nacjonalizacja” występuje w literaturze naukowej i obiegu potocznym w różnych zakresach znaczeniowych: od bardzo wąskich do bardzo szerokich, przy czym największe problemy sprawia nadawanie mu kontekstów zbyt pojemnych. Czytamy i słyszymy o fali nacjonalizacji na Zachodzie Europy po wielkim kryzysie gospodarczym, o nacjonalizacji niektórych banków podczas kryzysu finansowego 2008+ czy wreszcie - by przejść na rodzime podwórko - o nacjonalizacji części aktywów Otwartych Funduszy Emerytalnych ${ }^{1}$. Niekiedy można odnieść wrażenie, że nacjonalizacja to po prostu każdy przypadek poszerzania sektora publicznego,

1 J. Toninelli, From private to public to private again: a long-term perspective on nationalization, „Análise Social" 2008, Vol. 43, Nr 4, s. 682; R. Skidelsky, Keynes. Powrót mistrza, tłum. T. Krzyżanowski, M. Sutowski, Wydawnictwo Krytyki Politycznej, Warszawa 2012, s. 38; A. Łaszek, D. Samoń, M. Tatała, Opinia Forum Obywatelskiego Rozwoju nt. Projektu Ustawy o zmianie niektórych ustaw w zwiąku z określeniem zasad wypłaty emerytur ze środków zgromadzonych $w$ otwartych funduszach emerytalnych $z$ dnia 10 października 2013 r., [Warszawa], 28 października 2013, s. 2-4, www.FOR.pdf [dostęp 6.10.2014]. 
bez względu na sposób w jaki się dokonuje². Tymczasem takie podejście jest grubą nadinterpretacją.

Precyzyjnie rzecz ujmując, nacjonalizacja to tylko jedna $\mathrm{z}$ form tworzenia bądź powiększania sektora państwowego ${ }^{3} \mathrm{w}$ gospodarce, wymagająca - na zasadzie warunków koniecznych - zaistnienia dwóch okoliczności. Po pierwsze, implementującego aktu prawnego (ustawy, dekretu, rozporządzenia itp.), odnoszącego się adresowo do podmiotu gospodarczego (podmiotów gospodarczych) dotąd w ogóle, a przynajmniej w całości nieupaństwowionego (nieupaństwowionych). Po drugie, przymusowego transferu do sektora państwowego z rąk prywatnych, spółdzielczych czy samorządowych wszystkich znajdujących się w nich praw własności, czyli pełnego, a nie częściowego upaństwowienia. Inne okoliczności takiego transferu to kwestie wtórne. Prawa własności mogą więc przechodzić na państwo niepodzielnie lub w postaci akcji, za odszkodowaniem lub bez, równocześnie $\mathrm{z}$ aktem nacjonalizacji lub po pewnym czasie itd.

Teoretycznie warunek drugi (transfer praw własności) powinien być następstwem pierwszego (prawodawstwo nacjonalizacyjne), w praktyce jednak bywało różnie. Nacjonalizacja przemysłu w krajach socjalistycznych po II wojnie światowej w dużej mierze sankcjonowała stan faktyczny ukształtowany już uprzednio pod reżimem tzw. tymczasowych zarządów państwowych ${ }^{4}$. Bank Francji formalnie znacjonalizowano w grudniu 1945 r., ale w niemal pełnej zarządczej i częściowo własnościowej gestii państwa znalazł się on z górą osiem lat wcześniej5. Tak czy inaczej, nacjonalizacja to całkowite przejęcie przez państwo mocą przymusu prawnego własności gospodarczej przynależącej ${ }^{6}$ poprzednio w całości lub we fragmencie do podmiotu niepaństwowego (podmiotów niepaństwowych).

2 Np. D. Edgerton, Public ownership and the British arms industry, w: The political economy of nationalisation in Britain, 1920-1950, red. R. Millward, J. Singleton, Cambridge University Press, Cambridge 1995, s. 164.

3 Sektor państwowy nie jest oczywiście tym samym co sektor publiczny. W odróżnieniu od tego drugiego nie zalicza się doń np. własności municypalnej, ani też żadnych organów władzy centralnej, regionalnej czy lokalnej oraz podległych im instytucji. L. Tivey, Nationalization of British industry, rev. ed., Jonathan Cape Ltd., London 1973, s. 12-13; I. Lienert, Where does the public sector end and the private sector begin?, „IMP Working Paper, Fiscal Affairs Department”, June 2009, s. 5 (Tab. 1), 9-14, 26, www.inf.org./ external/pubs/ft/wp/2009 wp09122.pdf [dostęp 12.03.2016].

4 J. Luszniewicz, W kregu gospodarki centralnie kierowanej, w: Powszechna historia gospodarcza 1918-1931, red. W. Morawski, Floks, Warszawa 1994, s. 226. Tymczasowym zarządom państwowym podlegała własność państw i obywateli „osi”, rodzimych kolaborantów oraz osób zmarłych i nieobecnych.

5 A. Plessis, The history of banks in France, s. 6, www.fbf.fr/en/files/888HK2/History_banks_france_ EN.pdf [dostęp 18.10.2014]. Szerzej zob. C. Andrieu, La banque sous l'occupation. Paradoxes de l'histoire d'une proffesion, Presses de la Fondation Nationale des Sciences Politiques, Paris 1990, s. 31-41.

6 Nie wchodzę tu w rozróżnienia między poszczególnymi aspektami prawa własności: posiadaniem, użytkowaniem, rozporządzaniem, dysponowaniem itd. 
Wszystkie inne formy właścicielskiej ekspansji państwa w gospodarce - nabywanie na rynku akcji przedsiębiorstw prywatnych i innych, przejmowanie udziałów na poczet udzielonych lub niespłaconych kredytów, zakładanie przedsiębiorstw państwowych na tzw. surowym korzeniu (tj. w drodze inwestycji państwowych), ustanawianie monopoli skarbowych, reorganizacje i likwidacje powiększające zasięg sektora państwowego - to etatyzacja, a nie nacjonalizacja. Nie wymagają, choć oczywiście nie wykluczają odrębnych i adresowych aktów prawnych; nie muszą, choć mogą dotyczyć wyłącznie istniejących podmiotów gospodarczych; nie muszą, choć mogą kończyć się pełnym upaństwowieniem; mogą i najczęściej następują w trybie umownym.

Nawet jeśli nie zawsze udaje się precyzyjnie rozstrzygać wszystkie subtelności, a w konsekwencji odróżniać nacjonalizację od innych form etatyzacji (i odwrotnie), fundamentalne różnice uwidaczniają się na tyle często, że potrzeba definicyjnych delimitacji powinna być oczywista. W gospodarkach II Rzeczypospolitej i III Rzeszy sektory państwowe powiększały się bez kreujących bądź sankcjonujących tę tendencję adresowych aktów prawnych, a najczęściej też bez przejmowania całości akcji podporządkowanych podmiotów gospodarczych ${ }^{7}$. W większości państw socjalistycznych podległych ZSRR niemal zupełnie zlikwidowano prywatne rolnictwo, jednakże nie przy wykorzystaniu nacjonalizacji, i idzie tu nie tylko o tryb tworzenia quasi-kołchozów (spółdzielni produkcyjnych), ale i państwowych gospodarstw rolnych8. W latach 70. XX w. we Włoszech podmioty państwowe istniały w większości gałęzi gospodarki - górnictwie i hutnictwie, energetyce elektrycznej i atomowej, przemyśle maszynowym i stoczniowym, przemyśle naftowym i gazowym, bankowości i budownictwie, transporcie kolejowym, lotniczym i morskim, lączności i komunikacji - ale tylko w przypadku elektroenergetyki stało się tak na skutek nacjonalizacji.

7 Szerzej zob. J. Gołębiowski, Sektor państwowy w gospodarce Polski międzywojennej, PWN, Warszawa-Kraków 1985, s. 246-258, 277-284, 294 (tab. 49), 299 (tab. 51); U. Wengenroth, The rise and fall of stateowned enterprise in Germany, w: The rise and fall of state-owned enterprise in the western world, red. P. Toninelli, Cambridge University Press, Cambridge 2000, s. 115 i n.

8 K.E. Wädekin, Agrarian policies in communist Europe: a critical introduction (Studies in European \& Soviet Russian agrarian policy), Martinus Nijhoff Publishers. Allanheld, Osmun \& Co. Publishers Inc., The Hague-London 1982, passim; A. Stelmachowski, B. Zdziennicki, Prawo rolne, PWN, Warszawa 1980, s. 37, 49, 125-127, 239-240.

9 Przeprowadzono ją w 1962 r. A. Makać, Sektor państwowy w ekonomice rozwiniętych krajów kapitalistycznych, PWN, Warszawa 1971, s. 114, 126, 128; F. Di Porto, Energy law in Italy, Wolters Kluwer Law \& Business, b.m.w. 2011, s. 63. Była to jedyna nacjonalizacja we Włoszech po II wojnie światowej. Sektor państwowy rozszerzano tam głównie dzięki wykupom akcji przedsiębiorstw prywatnych przez wielkie publiczne koncerny, m.in. Instituto per la Riconstruzione Industriale (IRI) i Ente Nazionale Idrocarburi (ENI). Przejęte i kontrolowane firmy rozbudowywano następnie drogą inwestycyjną bądź kolejnych zakupów akcji. Z tego powodu zetatyzowaną część włoskiej gospodarki nazywano niekiedy „sektorem udziałów państwowych”. M.V. Posner, S.J. Woolf, Italian public enterprise, Gerald Duckworth \& Co, Ltd., London 1967, s. 26-36; K. Piotrowska-Hochfeld, Zagadnienia wzrostu gospodarczego Włoch, Warszawa 1964, s. 26 i n. 
Z powyższego - a przykłady można by mnożyć - wypływa kilka wniosków. Zależność między wielkością sektora państwowego a zasięgiem nacjonalizacji nie musi być wprost proporcjonalna. Nie każde przedsiębiorstwo państwowe powstaje w wyniku nacjonalizacji. Nie jest też nią nigdy państwowa kontrola, realizowana - choćby najściślej - przez specjalnie do tego celu powołane przedsiębiorstwa lub inne instytucje, ani też sam tylko udział państwa w kapitale akcyjnym, nawet wynoszący $100 \%{ }^{10}$. Nie mówiąc już o oddziaływaniu za pośrednictwem rządowych agencji regulacyjnych, jak w Stanach Zjednoczonych, co z reguły nie kończyło się nawet etatyzacją ${ }^{11}$.

Prezentowane tu rozumienie nacjonalizacji nie jest niczym nowym. Przeciwnie, ma silne ugruntowanie zarówno w literaturze zagranicznej, jak i polskiej ${ }^{12}$. Dlaczego zatem obecnie wymaga przypomnienia? Wydaje się, że problem ze zbyt szerokimi ujęciami terminu „nacjonalizacja”, występujący w jakiejś mierze zawsze, zaczął nasilać się od lat 90. XX w. Negatywnie oddziałały nań dyskusje nad koncepcjami i praktykami prywatyzacyjnymi toczone w krajach byłego bloku wschodniego. Prywatyzację przedstawiano $\mathrm{w}$ ich trakcie z reguły jako prostą odwrotność wcześniejszej nacjonalizacji ${ }^{13}$, co było o tyle nieuzasadnione, że nawet w tym kręgu geopolitycznym nie stanowiła ona wyłącznego narzędzia poszerzania własności państwowej. Wychodząc poza przykład socjalistycznego rolnictwa, można dodatkowo przywołać dwa epizody z pierwszych lat rządów komunistycznych w Polsce: akcję koncesyjno-likwidacyjną

10 Przypadek taki można zakwalifikować jako nacjonalizację, gdy odnośne przedsiębiorstwo działało uprzednio w innej formie własnościowej, a przejęciu wszystkich akcji przez państwo towarzyszył odpowiedni akt prawny.

11 S. Sztaba, Kapitalizm amerykański, w: Oblicza kapitalizmu, red. P. Jachowicz, S. Sztaba, Oficyna Wydawnicza SGH, Warszawa 2011, s. 27, 36-39; K. Michałek, Na drodze ku potędze. Historia Stanów Zjednoczonych Ameryki 1861-1945, Książka i Wiedza, Warszawa 1991, s. 96-98, 177-184, 186, 192-194. Jeden z nielicznych wyjątków to inwestycje w dolinie rzeki Tennessee z okresu New Dealu, skutkujące powstaniem pokaźnego sektora państwowego w energetyce. P. Kline, E. Moretii, Local economic development, agglomeration economies and The Big Push: 100 years of evidence from The Tennessee Valley Authority, November 2013, s. 4-5, www.eml.berkeley.edu// moretti/tva.pdf [dostęp 12.03.2016].

12 Por. M. Einaudi, Nationalisation of industry in Western Europe. Recent literature and debates, „The American Political Science Review" 1950, Vol. 44, Nr 1, s. 177-191; K. Katzarov, The theory of nationalisation, Martinus Nijhoff Publishers, The Hague 1964, s. 22 i n.; W. Sadzikowski, Wielka Brytania, w: W. Sadzikowski, J. Sikorski, A. Wieczorkiewicz, Sektor państwowy w kapitalizmie. Wielka Brytania, Francja, Austria, Włochy, PWN, Warszawa 1971, s. 11, 37 (przyp. 20); A. Makać, op.cit., s. 186-189; J. Luszniewicz, Nacjonalizacja, w: Nowa encyklopedia powszechna PWN, t. 4, Wydawnictwo Naukowe PWN, Warszawa 1996, s. 364-365; K. Osajda, Nacjonalizacja i reprywatyzacja, C.H. Beck, Warszawa 2009, s. 3 i n.; C. Coetzee, The proposed nationalization of mines in South Africa: a critical assessment, Province of KwaZulu-Natal, Provincial Treasury, IGR Unit, [2010], s. 5, www.kztnopbusiness.co.za/site/user_data/files/Mine_Nationalization_2pdf [dostęp 5.10.2014].

13 Przykładowo: K.Z. Poznański, Property rights perspective on evolution of communist-type economies, $\mathrm{w}$ : Constructing capitalism. The reemergence of civil society and liberal economy in the post-communist World, red. K.Z. Poznanski, Westview Press, Boulder, Col. 1992, passim; J. Buchanan, Post-socialist political economy. Selected essays, Edward Elgar Publishing, Cheltenham-Lyme, N.H. 1997, passim. 
wobec prywatnej bankowości (1945-1946) i tzw. bitwę o handel (1947-1948) ${ }^{14}$, a przede wszystkim etatyzację większości przemysłu, handlu wewnętrznego, transportu i pozostałej infrastruktury w NRD (1959-1972) ${ }^{15}$.

W debatach prywatyzacyjnych lat 90 . XX w., a także pierwszej dekady następnego stulecia opozycję znaczeniową nacjonalizacji i prywatyzacji wzmagały - czemu już dziwić się trudniej - rozbieżne wektorowo konotacje wartościowe. Nacjonalizacja uchodziła za synonim niemal całego zła w gospodarce, w każdym razie źródło nienormalności i nieefektywności; prywatyzacja - odwrotnie - długo reklamowana była jako najważniejszy środek leczniczy na chorobę upadłego socjalizmu ${ }^{16}$.

W dobie kryzysu finansowego 2008+ owo nadmiernie rozszerzone, a zarazem pejoratywne znaczenie terminu „nacjonalizacja”, dotąd najsilniej rozprzestrzenione w dawnym świecie socjalistycznym, mocno zakorzeniło się również na Zachodzie. Modne stało się mianowicie kwalifikowanie jako nacjonalizacji, w czym przodowali obrońcy ładu neoliberalnego, wielu przejawów antykryzysowego interwencjonizmu. W szczególności tych, które wiązały się z przechodzeniem w gestię państwa części akcji zagrożonych upadłością banków i korporacji prywatnych, bez względu na to, czy były to pakiety większościowe, czy mniejszościowe ${ }^{17}$. Neokeynesiści bywali tylko nieco bardziej subtelni. Potrzeba nie tyle dokapitalizowania banków, ile „pełnej nacjonalizacji istotnej części systemu gospodarczego" - perorował Paul Krugman, mając na myśli szerokie ogólnogospodarcze finansowe pakiety stymulacyjne ${ }^{18}$.

14 J. Kaliński, Bitwa o handel 1947-1948, Książka i Wiedza, Warszawa 1971, s. 106 i n.; Z. Landau, Czy w Polsce Ludowej dokonano nacjonalizacji banków, „Przegląd Historyczny” 1969, Vol. 60, Nr 4, s. 700-714.

15 W utworzonej w 1949 r. NRD nacjonalizacji sensu stricto nie przeprowadzono. Dokonano jej natomiast za okupacji radzieckiej w stosunku do bankowości, ubezpieczeń i części przemysłu (marzec 1948 r.). Wiele spośród „znacjonalizowanych” wówczas przedsiębiorstw, zwłaszcza o profilu militarnym, działało pod kamuflażem radzieckich spółek akcyjnych, będąc de facto własnością ZSRR. Proces przejmowania ich w gestię wschodnioniemiecką potrwał do $1953 \mathrm{r}$. W. Falk, Ogólne prawidłowości i specyficzne cechy socjalistycznej nacjonalizacji przemysłu w Niemieckiej Republice Demokratycznej, w: Nacjonalizacja w świecie współczesnym, Ksiażka i Wiedza, Warszawa 1978, s. 110-113, 115-119, 122-125, 131-135; W. Brus, Histoire économique de l'Europe de l'est, Le Découverte, Paris 1986, s. 16-18 i n.

16 Zob. uwagi o atmosferze wokół konceptów nacjonalizacji i prywatyzacji na ówczesnych konferencjach naukowych. P. Toninelli, op.cit., s. 675-676.

17 Np. M.A. Edwards, Nationalization, de-nationalization, re-nationalization. Some historical and comparative perspective, „Pace Law Review” 2009, Vol. 30, Nr 1, s. 123-153.

18 P. Krugman, What to do, „The New York Review of Books”, 18.12.2008 (cyt. za R. Skidelsky, op.cit., s. 72-73). 


\section{Nacjonalizacja w praktyce: zarys chronologiczny i typologiczny}

Do 1945 r. sektor państwowy tworzono i rozbudowywano metodami na ogół innymi niż nacjonalizacja. W ujęciach generalnych bywa ona więc określana jako zjawisko początkowo „incydentalne” (przed I wojny światową), a później co najwyżej „sporadyczne” (w międzywojniu) ${ }^{19}$. Dostępny materiał faktograficzny w zasadzie potwierdza tę ocenę.

Przed 1914 r. cechy nacjonalizacji wykazywały niektóre przejęcia dóbr ziemskich (np. majątków kościelnych we Francji podczas wielkiej rewolucji), linii kolejowych (szczególnie w Japonii w latach 1906-1907) oraz nowych technologii telekomunikacyjnych (np. linii telegraficznych i telefonicznych w Wielkiej Brytanii w latach 1869 i 1912) ${ }^{20}$. W Europie pierwszą nacjonalizację sensu stricto przeprowadzono w $1912 \mathrm{r}$. we Włoszech wobec części sektora ubezpieczeń ${ }^{21}$. Kryterium gałęziowo-branżowe było oczywiście najczęstsze, ale nie wyłączne. Przykładowo: w 1916r. w Wielkiej Brytanii na mocy ustaw parlamentarnych znacjonalizowano produkcję, dystrybucję i sprzedaż piwa w rejonach Carlisle, Gretny, Cromarty Firth i Enfield ${ }^{22}$. Po I wojnie światowej nacjonalizacją na szeroką skalę posłużyły się dyktatury komunistyczne; dotyczyło to nie tylko Rosji Radzieckiej (ZSRR), ale także Mongolii oraz efemerycznych tworów państwowych w rodzaju Węgierskiej Republiki Rad czy Bawarskiej Republiki Rad.

Nacjonalizacja w bolszewickiej Rosji obejmowała kolejno i bez odszkodowania: ziemię, bankowość, transport, przemysł i handel wewnętrzny ${ }^{23}$. W praktyce w bezpośrednim władaniu bolszewickiego państwa-partii znalazła się - i to już w końcu 1920 r. - niemal cała gospodarka pozarolnicza (późniejszy okres NEP-u przyniósł

19 K. Katzarov, op.cit., s. 75.

20 J. Dunn, Secularizing the sacred: the effort to dechristianize France during the French Revolution, „Primary Source" 2012, Vol. 4, Nr 1, s. 27; M. Imashiro, Nationalisation of railways and dispute over reconstruction to standard gauge, „Japan Railway \& Transport Review”, March 1995, s. 42-45, www.jrtr.net/jrtr.04/pdf/history/pdf [dostęp 6.10.2014]; L. Tivey, op.cit., s. 63-64.

21 R. Pearson, Escaping from the state? Historical paths to public and private insurance between the eighteenth and twentieth centuries, $\mathrm{X}$ Congreso Internacional de la Associación Española de Historia Ecónomica (AEHE), Carmona, 8-9 September 2011, s. 14, www.aehe.net/xcongreso/pdf/sesiones/seguros.pdf [dostęp 6.10.2014].

22 T.R. Gourvish, The business alcohol in the USA and the UK: UK regulation and drinking habits, 1914-1939, „Business and Economic History” 1997, Vol. 26, Nr 2, s. 610.

23 Wyłączną domeną państwa stał się też handel zagraniczny. Osiągnięto to nie poprzez nacjonalizację, ale uznanie działalności eksportowej i importowej za monopol państwa (kwiecień 1918 r.). Odtąd, z niewielkimi i krótkotrwałymi wyjątkami, handlem zagranicznym zajmowały się specjalnie w tym celu tworzone podmioty państwowe. A. Baykov, The development of the Soviet economic system, Cambridge University Press, Cambridge-New York 1947, s. 28, 71-74, 77, 264, 266-268. 
wyłomy niewielkie i nietrwałe). Natomiast znacjonalizowaną ziemię pozwalano aż do czasów powszechnej kolektywizacji rolnictwa użytkować indywidualnym gospodarstwom. Nie licząc lat komunizmu wojennego, mogły czynić to stosunkowo swobodnie ${ }^{24}$. Na wzorcu radzieckim ściśle opierano się w Mongolii. Ze względu jednak na brak przemysłu, banków, transportu drogowego i kolejowego itd. praktyczne znaczenie miała tam tylko nacjonalizacja ziemi i późniejsze próby skolektywizowania rolnictwa ${ }^{25}$. W komunistycznych republikach proklamowanych w Bawarii i na Węgrzech, wskutek ich rychłego upadku, rozległe projekty nacjonalizacyjne pozostały póki co świadectwem intencji ${ }^{26}$.

W innych państwach europejskich, niezależnie od rozrostu interwencjonizmu, w tym etatyzmu, nacjonalizacja zdarzała się w międzywojniu dość rzadko. Najwcześniejszym przykładem jest prawodawstwo austriackie z $1919 \mathrm{r}$. Na jego podstawie do 1930 r. znacjonalizowano „15 niewielkich spółek akcyjnych w przemyśle tekstylnym, 25 mniejszych spółek bankowych i 7 spółek w przemyśle skórzanym i obuwniczym"27. Przywoływane często w kontekście nacjonalizacji poszerzenia sektorów państwowych pod rządami rozmaitych reżimów faszystowskich i autorytarnych były w zdecydowanej większości etatyzacjami. Za pośrednictwem aktów prawnych własność państwową rozbudowywano za to w Wielkiej Brytanii i Francji, dwóch najsilniejszych demokracjach parlamentarnych o wysoko rozwiniętych i uprzemysłowionych gospodarkach. W Wielkiej Brytanii państwo przejęło tą metodą stacje nadawcze (1926r.; w danym momencie tylko radiowe), część przesyłu elektryczności (1926r.), transport pasażerski w Londynie (1933 r.; z wyjątkiem kolei), złoża ropy naftowej (1934 r.) i węgla kamiennego (1938 r.), linie lotnicze obsługujące trasy zagraniczne (1939 r.), trzy firmy przemysłu lotniczego (lata 1943 i 1944) ${ }^{28}$. We Francji znacjonalizowano niemal cały przemysł lotniczy, niektóre fabryki pracujące na potrzeby armii oraz - w sposób dość specyficzny - spółki kolejowe (wszystko w latach 1936-1937)²9.

24 Więcej o nacjonalizacji w komunistycznej Rosji zob. J. Luszniewicz, Gospodarka radziecka w latach 1917-1841, w: Powszechna historia..., s. 87-89, 92, 96-97, 104.

25 W.E. Butler, The Mongolian legal system. Contemporary legislation and documentation, Martinus Nijhoff Publishers, The Hague 1982, s. XVI, XVIII, 510; Baarbar [B.-E. Batbajar], Dzieje Mongolii, tłum. S. Grodziński, Dialog, Warszawa 2005, s. 320-321, 361, 374-378, 395-396.

26 J. Kochanowski, Wegry. Od ugody do ugody. 1867-1990, Trio, Warszawa 1997, s. 54-56; A. Mitchell, Revolution in Bavaria, 1918-1919: the Eisner Regime and the Soviet Republic, Princeton University Press, Princeton, N.J. 1965, s. 304 i n.

27 J. Sikorski, Austria, w: W. Sadzikowski, J. Sikorski, A. Wieczorkiewicz, op.cit., s. 171-172.

28 A. Makać, op.cit., s. 35-38; P. Howlett, „The thin end of the wedge?”: nationalisation and industrial structure during the Second World War, w: The political..., op.cit., s. 237. Nacjonalizacja złóż węgla i ropy nie objęła sfer eksploatacji i obrotu.

29 A. Makać, op.cit., s. 88-90. Całą istniejącą sieć kolejową prywatną i państwową podporządkowano nowo utworzonej spółce mieszanej Société Nationale des Chemins de Fer Français (SNCFN). Państwo miało 
Poza kontynentem europejskim przodowała Ameryka Łacińska. Przykładowo: w Meksyku stopniowo dokonano nacjonalizacji transportu kolejowego i przemysłu naftowego (lata 1908, 1934 i 1937-1938). W mniejszej skali, ale również głównie w sektorze infrastrukturalnym i surowcowym, nacjonalizowano w Argentynie, Boliwii, Brazylii, Chile i Wenezueli ${ }^{30}$.

Całkowicie nowy etap rozpoczął się wraz z zakończeniem II wojny światowej. Przede wszystkim bardzo szeroką nacjonalizację zaczęły przeprowadzać europejskie państwa socjalistyczne. Najdalej posunięto się w Albanii (1944-1947), gdzie na własność państwa przeszła tą drogą praktycznie cała gospodarka pozarolnicza, łącznie z dużą częścią zakładów rzemieślniczych ${ }^{31}$. W Jugosławii (1944-1946, 1948 r.), Czechosłowacji (lata 1945 i 1948), na Węgrzech (1945-1949), w Polsce (1946 r.), Rumunii (lata 1946, 1948-1949) i Bułgarii (1947-1949) akty nacjonalizacyjne skutkowały włączeniem do sektora państwowego absolutnej większości przemysłu (z górnictwem i budownictwem), bankowości, ubezpieczeń, transportu, łączności, telekomunikacji i pozostałej infrastruktury, a niekiedy też części handlu wewnętrznego (w Jugosławii) ${ }^{32}$. Generalnie jednak w tej ostatniej dziedzinie własności państwowej nie powiększano za pośrednictwem nacjonalizacji, ale rozmaitych działań etatyzacyjnych. Stosowano je również w przemyśle, nie tylko przed, ale i po formalnej nacjonalizacji. Czasami etatyzacjami posługiwano się zamiast nacjonalizacji. Tak było np. w znanych już przypadkach polskiej bankowości czy NRD-owskiego przemysłu, a w skali całego bloku w sferze handlu zagranicznego (w ramach państwowych monopoli).

Powojenna nacjonalizacja socjalistyczna, z wyjątkiem represyjnej, inaczej niż w bolszewickiej Rosji, odbywać się miała za odszkodowaniem, zwykle częściowym dla kapitału krajowego i pełnym dla zagranicznego. W praktyce w pierwszym przypadku odszkodowań albo w ogóle nie wypłacano, albo czyniono to w mniejszym od zapowiedzianego wymiarze. W drugim przypadku pod rozmaitymi pretekstami

w niej 51\% udziałów, ale zobowiązało się do 1982 r. przymusowo wykupić wszystkie pozostałe akcje prywatne. W istocie była to więc etatyzacja z zapowiedzią przyszłej nacjonalizacji.

30 M. Rubio, Oil and economy in Mexico, 1900-1930 s., Universitad Pompeu Fabia, Department of Economics and Business (Barcelona, Spain), s. 1-15, www.ecom.upf.edu/docs/papers/downloads/690.pdf [dostęp 17.10.2014]; M. Bucheli, S. Decker, Economic nationalism in Latin America and Africa in the twentieth century: a comparison, [2014], s. 6, 11-13, www.worldbhc.org/files/fullprogram/A2_B2_DekerBucheli2014Econom.pdf [dostęp 15.03.2016].

31 N. Kołomejczyk, Rewolucje ludowe w Europie 1939-1948, Wiedza Powszechna, Warszawa 1973, s. 215, 357. Idzie tu rzecz jasna o przodownictwo pod względem zakresu gałęziowego, a nie liczby czy wielkości znacjonalizowanych podmiotów gospodarczych. Albania była najbardziej zacofanym gospodarczo państwem Europy, niemal pozbawionym przemysłu przetwórczego. Reżim komunistyczny miał tu więc niewiele do nacjonalizowania.

32 Por. K. Katzarov, op.cit., s. 56-65; Z. Kołomejczyk, op.cit., s. 214-220, 357-359; B. Brzeziński, Kalendarium ważniejszych wydarzeń dotyczacych nacjonalizacji przemystu w socjalistycznych krajach Europy, w: Nacjonalizacja w świecie współczesnym, op.cit., s. 391-404. 
starano się opóźniać wypłaty. Kwestie sporne regulowano następnie w dwustronnych układach z państwami zachodnimi ${ }^{33}$.

W znacznie węższej skali nacjonalizację wykorzystywały europejskie państwa kapitalistyczne, choć w porównaniu z międzywojniem wzrost pod względem liczbowym i zakresowym był spektakularny. W pierwszych latach po II wojnie światowej dotyczyło to jednak tylko Austrii, Francji i Wielkiej Brytanii. Nacjonalizacja w tych państwach zostanie omówiona w dalszych częściach artykułu. W innych gospodarkach zachodnioeuropejskich sektor państwowy powiększał się w tym czasie przede wszystkim w wyniku etatyzacji.

W kolejnych dekadach nacjonalizacja po zachodniej stronie „żelaznej kurtyny” stała się częstsza. Relatywnie największa miała miejsce w Wielkiej Brytanii (lata 1967, 1971, 1973-1974, 1977), Portugalii (1974-1976) i Francji (1981-1982)34. Równolegle w tych i innych gospodarkach trwały etatyzacje. W rezultacie rozmiary sektora państwowego na Zachodzie Europy na przełomie lat 70. i 80. były rekordowe. W najbardziej zaawansowanych pod tym względem Austrii, Francji i Włoszech wytwarzał on około $14-16 \%$ ogółu produkcji przemysłowej ${ }^{35}$.

W krajach bloku wschodniego nacjonalizacja i etatyzacje, wraz z centralnym planowaniem i zarządzaniem, służyły przede wszystkim budowaniu omnipotencji gospodarczej socjalistycznego państwa. Z jednej strony miało ono stać na straży impoderabiliów doktryny i ustroju, a z drugiej strony przeprowadzić modernizację gospodarczą, poczynając od narzucenia industrializacji via przemysł ciężki ${ }^{36}$. Odmienne podejście ukształtowało się jedynie w Jugosławii, gdzie od 1950 r. w znacjonalizowanych przedsiębiorstwach rozwijano samorząd robotniczy, widząc w nim drogę do

33 Polska i Węgry zawierały je jeszcze na początku lat 70. Zob. W. Dudek, Nacjonalizacja jako przedmiot stosunków Polski z niektórymi państwami kapitalistycznymi, w: ibidem, s. 172, 176.

34 L. Hannah, A failed experiment: the state ownership of industry, w: The Cambridge economic history of modern Britain, Vol. III, Structural change and growth, 1939-2000, red. F. Floud, P. Johnson, Cambridge University Press, Cambridge 2004, s. 89 (Tab. 4.2); A.B. Nunes, C. Bastien, N. Valério, Nationalizations and de-nationalizations in Portugal (1 $9^{\text {th }}$ and $20^{\text {th }}$ Centuries): a historical assessment, Documento de Trabalho, „Working Paper” Nr 22, GHES, Lisboa 2005, s. 15-20, https://aguila1.iseg.ulisboa.pt.pdf [dostęp 13.10.2014]; R. Holton, Industrial politics in France: nationalisation under Mitterrand, „West European Politics” 1986, Vol. 9, $\mathrm{Nr}$ 1, s. 67-80.

35 Por. R.P. Short, The role of public enterprises: an international statistical comparison, w: R.H. Floyd, C.S. Gray, R.P. Short, Public enterprises in the mixed eonomies. Some macroeconomic aspects, International Monetary Fund, Washington, D.C. 1984, s. 116-117 (Tab. 1); L. Pathirane, D. Blades, Defining and measuring the public sector: some international comparisons, „Review of Income and Wealth” 1984, Vol. 28, Nr 3, s. 271, 273.

36 Pojęcie „modernizacji” utożsamiam - za Witoldem Morawskim - z „wiązką procesów ekonomicznych, politycznych, społecznych i kulturowych, w których toku dokonuje się transformacja krajów nierozwiniętych (mniej rozwiniętych) w rozwinięte (bardziej rozwinięte)". W. [Witold] Morawski, Wprowadzenie, w: Modernizacja Polski. Struktury, agencje, instytucje, red. W. [Witold] Morawski, Wydawnictwa Akademickie i Profesjonalne. Akademia Leona Koźmińskiego, Warszawa 2010, s. 19. 
faktycznego uspołecznienia własności, uzyskania równowagi między sferami inwestycji i konsumpcji oraz stopniowego otwierania gospodarki na impulsy rynkowe ${ }^{37}$.

W Europie Zachodniej nacjonalizację (i etatyzacje) traktowano jako jedno z narzędzi interwencjonizmu państwowego, niezbędnego do korygowania mechanizmu rynkowego. Własność państwowa pozwalała podtrzymywać, rozwijać oraz kontrolować gałęzie i przedsiębiorstwa o charakterze użyteczności publicznej, obniżonej rentowności, niedostatecznym doinwestowaniu, nadmiernej monopolizacji itp. Motywacje czysto polityczne występowały rzadziej, a doktrynalne czy ideologiczne raczej wyjątkowo. Własność prywatną, mimo jej ograniczania, nadal uznawano za konstytutywną podstawę systemu gospodarczego ${ }^{38}$. Dlatego też regułą było przeprowadzanie nacjonalizacji za pełnym odszkodowaniem, zarówno formalnie, jak i faktycznie ( $\mathrm{z}$ wyłączeniem wywłaszczeń karnych). $Z$ tego też powodu znacjonalizowane firmy zachodnie $\mathrm{w}$ wielu aspektach przypominały podmioty z sektora prywatnego - posiadały status osób prawnych, kierowały się zasadami komercyjnymi, próbowały osiągać zyski. Zarazem były nadzorowane przez organy władzy państwowej.

Dla zabezpieczenia owego nadzoru powoływano zwykle specjalne państwowe korporacje, koncerny bądź holdingi, integrujące na zasadzie wspólnoty gałęziowej lub branżowej większe grupy znacjonalizowanych podmiotów. Pomysł wywodził się z praktyki brytyjskiej, gdzie struktury takie - zwane korporacjami publicznymi - w zalążkowej formie tworzono już w XIX w., a w pełnej postaci ukształtowały się w okresie międzywojennym ${ }^{39}$. Klasyczna brytyjska korporacja publiczna była własnością państwa, zarząd pochodził z nominacji odpowiedniego ministra, działalność musiała uwzględniać priorytety rządu itd., ale $\mathrm{z}$ formalnego punktu widzenia stanowiła byt odrębny od administracji centralnej i lokalnej, dzięki czemu zachowywała na wielu polach swobodę decyzyjną (większą przed, mniejszą po II wojnie światowej $)^{40}$.

Pośrednia, a nie bezpośrednia podległość wobec władz państwowych to tylko jedna strona medalu. Równocześnie bowiem korporacje publiczne i inne instytucje kierujące państwowymi przedsiębiorstwami powiększały stopień koncentracji,

\footnotetext{
37 J. Kleer, Jugostawiańska reforma gospodarcza, Książka i Wiedza, Warszawa 1970, passim.

38 Dlatego na Zachodzie regułą było przeprowadzanie nacjonalizacji za pełnym odszkodowaniem, zarówno formalnie, jak i faktycznie ( $\mathrm{z}$ wyłączeniem wywłaszczeń karnych).

39 L. Tivey, op.cit., s. 29-32; W. Sadzikowski, op.cit., s. 23-25.

40 L. Tivey, op.cit., s. 33-34, 64-65, 99-101. Tamże wyczerpująca analiza relacji brytyjskich korporacji publicznych z rządem po 1945 r., jak również niektórych problemów ich wewnętrznego funkcjonowania (s. 125-161).
} 
monopolizacji i biurokratyzacji gospodarki ${ }^{41}$. Problemy stwarzały też częste zmiany reguł organizacyjnych i zakresów kompetencyjnych. Do zasadniczych modyfikacji na obu tych polach dochodziło zwłaszcza w Austrii i Francjii ${ }^{42}$.

Po II wojnie światowej nacjonalizacji dokonywano również w Ameryce Łacińskiej, Afryce i Azji. Była ona wymierzona głównie w kapitał zagraniczny, ulokowany we własności ziemskiej, bankowości, ubezpieczeniach, infrastrukturze gospodarczej, handlu zagranicznym i przemyśle surowcowym. Ograniczenie, a niekiedy nawet eliminację kapitału obcego traktowano jako warunek sine qua non samodzielnej polityki industrializacji i modernizacji. Dosyć często w grę wchodziły także motywy ideologiczne, $\mathrm{z}$ reguły $\mathrm{w}$ związku z próbami realizacji różnych odmian systemu socjalistycznego. W takich przypadkach nacjonalizacja okazywała się zresztą zakresowo największa (Korea Północna po roku 1946, ChRL po roku 1949, Wietnam Północny po roku 1954, Kuba po roku 1959 itd.). Specyfiką odznaczała się również nacjonalizacja afrykańska, służąca zawłaszczaniu istniejącego majątku gospodarczego przez nowe postkolonialne elity władzy. W całym tzw. trzecim świecie, licząc od zakończenia wojny do przełomu lat 80 . i 90 . XX w., nacjonalizację przeprowadziło w różnym czasie i zakresie blisko 80 państw. Przeważająca część aktów nacjonalizacyjnych zawierała klauzule odszkodowawcze, jednak w rzeczywistości rekompensaty były zaniżane, albo niewypłacane w ogóle $e^{43}$.

Generalnie rzecz biorąc, rola sektora państwowego w Ameryce Łacińskiej, Afryce i Azji była wyraźnie większa niż na Zachodzie, ale mniejsza niż w gospodarkach ZSRR i jej europejskich satelitów (pomijając Koreę Płn., ChRL i parę innych pozaeuropejskich dyktatur socjalistycznych). Udział sektora państwowego w produkcji ogółem w bardziej zaawansowanych gospodarkach trzeciego świata szacowano na 10-25\%, a w słabiej rozwiniętych - często znacznie powyżej $25 \%$ (wczesne lata $80 .{ }^{44}$.

41 Przykłady z praktyki francuskiej i brytyjskiej zob. D. Barjot, To rebuild France after WW2: the beginnings of électricité de France (1946-1953), EBHA conference, 24-26 August 2011, Athens, s. 1-2, 11-12, www.ebha.org/ebha2011/files/Papers/Athens.pdf [dostęp 12.10.2014]; L. Hannah, op.cit., s. 94.

42 Por. E. Langer, Nationalisations in Austria, „Annals of Public and Cooperative Economics” 1964, Vol. 35, Nr 2-3, s. 121-122; A. Wieczorkiewicz, Francja, w: W. Sadzikowski, J. Sikorski, A. Wieczorkiewicz, op.cit., s. 110-120.

43 Szerzej zob. J. Kleer, Nacjonalizacja $w$ Trzecim Świecie, w: Nacjonalizacja w świecie współczesnym, op.cit., s. 381-387; J. Luszniewicz, Nacjonalizacja, op.cit., s. 364-365; M. Buchelli, S. Decker, op.cit., s. 6-7, 13, 30; L. Rood, Nationalisation and indigrenisation in Africa, „The Journal of Modern African Studies” 1976, Vol. 14, Nr 3, s. 427-447.

44 R.P. Short, op.cit., s. $115,118-122$ (Tab. 1). 


\section{Powojenna nacjonalizacja zachodnioeuropejska: tło polityczne}

W literaturze przedmiotu przyczyny nacjonalizacji - i szerzej wzrostu sektora państwowego - dzielone są konwencjonalnie na: ekonomiczne, społeczne i polityczne. Każdy z tych trzech motywów sam w sobie stanowi oczywiście szerszą ich kategorię. I tak, za warianty motywacji ekonomicznej uznaje się np. oczekiwanie, że nacjonalizacja wpłynie w dany sposób na wysokość cen, rentowność produkcji czy tempo industrializacji; za warianty motywacji społecznej - np. stawkę na określone skutki w sferze zatrudnienia, stosunków pracy czy sytuacji socjalnej; za warianty motywacji politycznej - np. wszelkie ideologiczne i doktrynalne uzasadnienia nacjonalizacji, racjonalizowanie jej twierdzeniami o wyższości własności państwowej nad innymi jej typami, traktowanie jako narzędzia powiększania decyzyjnej domeny państwa itd. Wielu autorów podkreśla, że regułą jest raczej współwystępowanie motywów różnych kategorii niż wyłączność którejś z nich, przypadkiem zaś dość częstym trudności identyfikacyjne, niemożność ścisłych rozgraniczeń, a nawet kolizje i sprzeczności ${ }^{45}$.

Pomimo świadomości tych komplikacji dyskurs na temat przyczyn nacjonalizacji zatrzymuje się zwykle na poziomie ogólnym, abstrahując od konkretnych historycznych uwarunkowań sytuacyjnych, w szczególności wewnątrzpaństwowych. Innymi słowy, dla nacjonalizacji przeprowadzanej w XIX stuleciu i przed I wojną światową, w latach międzywojennych oraz po II wojnie światowej podaje się zasadniczo te same bądź zbliżone kombinacje motywacji, nie tylko w ujęciu generalnym, ale i w odniesieniu do poszczególnych państw ${ }^{46}$. Nie jest to praktyka najszczęśliwsza, ponieważ, po pierwsze, uwarunkowania sytuacyjne w każdym z tych okresów bywały różne, zaś po drugie, właśnie na poziomie wewnątrzpaństwowym w istocie przesądzało się wszystko: czy w ogóle oraz w jakim zakresie i na jakich zasadach dokonywać nacjonalizacji.

W interesującej nas tu drugiej połowie lat 40. XX w. kluczową rolę sprawczą odegrały względy natury politycznej, a mówiąc bardziej precyzyjnie, kształt i ewolucja powojennych układów rządzenia. Od nich bowiem zależało, czy i na ile siły pronacjonalizacyjne znajdą przestrzeń do realizowania swoich zamierzeń ${ }^{47}$.

45 Np.P. Toninelli, op.cit., s. 677-680.

46 Np.K. Katzarov, op.cit., s. 21-81; The rise..., op.cit., s. 103-272 [teksty różnych autorów - J.L.]; T. Hafsi, Privatization and nationalization, w: Encyclopedic dictionary of public administration, red. L. Côté, J.F. Savard, s. 2, [on-line], www.dictionnaire.enap.ca.pdf [dostęp 3.03.2016].

47 O decydującym znaczeniu „politycznego środowiska” dla możliwości przeprowadzenia oraz ostatecznego kształtu nacjonalizacji wspominał m.in. J. Singleton, Labour, the Conservatives and nationalisation, w: The political..., op.cit., s. 29. 
To dlatego tak wiele upaństwawiały dyktatury marksistowskie i marksizmem się inspirujące. Doktryna ta bowiem od zawsze za wrogów miała rynek, pieniądz i własność prywatną, a nowy system gospodarczy, jaki lansowała, opierać chciała na ich zaprzeczeniu ${ }^{48}$. Zawłaszczanie władzy politycznej przez adherentów marksizmu każdorazowo więc przekształcało teorię w praktykę. Na podobnej zasadzie pole do nacjonalizacji otwierało się w nowych państwach Azji i Afryki rządzonych przez miejscowe antyzachodnie elity postkolonialne. Mieszanki nacjonalizmu, socjalizmu, populizmu i rozmaitych miejscowych „-izmów” nieuchronnie wynosiły na piedestał instytucję państwa, również w kontekście układu własności w gospodarce (nawet jeśli państwo to było tylko „teoretyczne”). Zbliżony mechanizm funkcjonował w Ameryce Łacińskiej, zwłaszcza w przypadku autorytarnych i półautorytarnych dyktatur zorientowanych na ekonomię rozwoju i teorie modernizacji ${ }^{49}$.

Polityczne uwarunkowania określiły też klimat dla polityki gospodarczej w Europie Zachodniej. W trakcie wojny i bezpośrednio po jej zakończeniu doszło tam do widocznego przesunięcia się nastrojów „w lewo”. Skorzystały na tym - w różnym stopniu i zakresie czasowym - trzy siły polityczne: komuniści, socjaldemokraci (socjaliści) oraz chrześcijańscy demokraci. Największego awansu doświadczyli ci pierwsi. W wielu państwach zachodnich wskutek swej roli w ruchu oporu i (lub) wyników demokratycznych wyborów współtworzyli oni pierwsze powojenne koalicje rządowe. Najsilniejsze partie komunistyczne działały we Francji i Włoszech (wspierane przez potężne związki zawodowe), ale komuniści mieli swoich ministrów również w rządach austriackim, belgijskim, duńskim, islandzkim i większości niemieckich landów. Początkowo prezentowali taktykę raczej koncyliacyjną. Nie forsowali szczególnie radykalnych postulatów, niekiedy wydawać się nawet mogło, że ustępują na tym polu socjaldemokratom, z którymi - jako z lewicą - deklarowali współpracę (podobnie jak z partiami centrolewicowymi). Znamienne, że w niektórych partiach komunistycznych, np. norweskiej, francuskiej czy niemieckiej, pojawiały się głosy za zjednoczeniem z socjaldemokratami. $Z$ dominującego trendu wyłamali się tylko komuniści belgijscy i greccy. Pierwsi nieudanie próbowali drogą demonstracji ulicznych obalić demokratyczny rząd i przejąć władzę. Drudzy wszczęli regularną wojnę partyzancką, którą ostatecznie przegrali ${ }^{50}$.

48 A. Walicki, Marksizm i skok do królestwa wolności. Dzieje komunistycznej utopii, Wydawnictwo Naukowe PWN, Warszawa 1996, s. 16-20, 93-99.

49 Zob. np. A. Leszczyński, Skok w nowoczesność. Polityka wzrostu w krajach peryferyjnych 1943-1980, Wydawnictwo Krytyki Politycznej, Warszawa 2013, s. 365-425. Tamże w części bibliograficznej (s. 527-567) bogaty wybór literatury przedmiotu.

$50 \mathrm{Na}$ temat polityki komunistów belgijskich i greckich zob. R. Hemmerijckx, The Belgian Communist Party and the socialist trade unions, 1940-60, „Journal of Communist Studies and Transition Politics” 1990, 
Na korzyść zachodnioeuropejskich komunistów bezpośrednio po wojnie bardzo grała autentyczna sympatia społeczna do ZSRR jako pogromcy III Rzeszy ${ }^{51}$. Pomagała też naiwność zachodniej opinii publicznej. Zwalczanie przez oddziały brytyjskie partyzantki komunistycznej w Grecji kontestowała nie tylko lewica, ale również większość angielskiej prasy, łącznie $\mathrm{z}$ „The Times” ${ }^{\prime 2}$. „W powszechnym mniemaniu komunizm był niczym więcej, jak tylko ruchem na rzecz radykalnych reform demokratycznych i społecznych. Miał, co prawda, kilka niemiłych aspektów, niemniej - uwzględniając wszystkie okoliczności - znakomicie nadawał się dla krajów, które cierpiały na brak trwałych tradycji demokracji" - odtwarzał panujące nastroje Walter Laqueur ${ }^{53}$. Na kontynencie tego typu opinie rozpowszechniały się tym łatwiej, im mniej bezpośrednich kontaktów mieli z ZSRR potencjalni sympatycy. W państwach radzieckiej strefy wpływów nastroje, z małymi wyjątkami, kształtowały się odmiennie. Podobnie było w zachodnich Niemczech i Austrii, gdzie doświadczono bezpośredniego kontaktu z Armią Czerwoną. Dlatego m.in. wpływy tamtejszych partii komunistycznych przedstawiały się na tle pozostałych krajów zachodnich wyjątkowo mizernie ${ }^{54}$.

Wielkim wygranym pierwszych lat powojennych były też siły polityczne odwołujące się do demokratycznej i reformistycznej tradycji socjalizmu. Partie socjaldemokratyczne bądź socjalistyczne rządziły samodzielnie w Wielkiej Brytanii i niektórych państwach skandynawskich, współrządziły zaś niemal wszędzie indziej, regularnie uzyskując w wyborach od kilkunastu do czterdziestu paru procent głosów (najwięcej Socjaldemokratyczna Partia Szwecji i brytyjska Partia Pracy $)^{55}$. Dalsze perspektywy zależały od dwóch okoliczności: pozycji politycznej komunistów, z którymi rywalizowano o ten sam elektorat, oraz zdolności przyciągnięcia wyborców z warstw średnich. Początkowo zdecydowanie najlepiej radziła sobie brytyjska Partia Pracy, dzięki najpłytszemu z całej zachodnioeuropejskiej lewicy zakorzenieniu w marksizmie oraz wynikającej stąd tradycyjnej ponadklasowości. Skupiając różne orientacje ideowe,

Vol. 6, Nr 4, s. 124-142; T.D. Sfikas, War and peace in the strategy of the Communist Party of Greece, „Journal of Cold War Studies" 2001, Vol. 3, Nr 3, s. 5-30.

51 R. Miliband, Parliamentary socialism: a study in the politics of Labour, $2^{\text {nd }}$ rev. ed., Merlin Press, London 2009, s. 273.

52 J. Sakkas, „The Times” and the British intervention in Greece in December 1944, „Balkan Studies” 2012, Vol. 46, s. 27-38.

53 W. Laqueur, Historia Europy 1945-1992, tłum. R. Zawadzki, Puls, Londyn 1993, s. 60.

54 Komuniści austriaccy uzyskiwali w wyborach 5,4\% i 5,1\% oddanych głosów (lata 1945 i 1949), a zachodnioniemieccy 5,7\% (1949 r.). We Francji komuniści zdobywali w tym czasie między 25,95 a 28,3\% głosów, a we Włoszech - od 18,9\% do 30,7\% (w koalicji z socjalistami Pietro Nenniego). D. Nohlen, P. Stöver, Elections in Europe: a data handbook, $15^{\text {th }}$ ed., Nomos, Baden-Baden-Chicago 2010, s. 213, 688-689, 762, 1047-1048.

55 Ibidem, s. 1872, 2023. 
wśród których marksizm, na ogół zresztą umiarkowany, nie był częstszy od socjalizmów gildyjnego, chrześcijańskiego i fabiańskiego, liberalizmu socjalnego, kooperatyzmu czy tradeunionizmu, labourzyści nie mieli żadnego poważnego konkurenta do korzystania na zwrocie ku postawom lewicowym ${ }^{56}$. Zapotrzebowanie na radykalizm doskonale zabezpieczało lewe skrzydło Partii Pracy, a Partia Komunistyczna Wielkiej Brytanii pozostała na politycznym marginesie (poniżej 0,4\%, 0,3\% i 0,08\% głosów w wyborach parlamentarnych lat 1945, 1950 i 1951) $)^{57}$.

Socjaliści i socjaldemokraci na kontynencie, wyrastając bezpośrednio z pnia marksistowskiego, musieli w toku swej historii przezwyciężać pierwotne rewerencje dla „rewolucji społecznej” i „dyktatury proletariatu”, godzić się z reformizmem i demokracją parlamentarną, krótko mówiąc, rewidować „założycielskie” idee. W rezultacie mieli znacznie silniejszą partyjną lewicę, prącą do współpracy, a nawet zjednoczenia z komunistami. W przypadku Socjaldemokratycznej Partii Niemiec (SPD) dla zapobieżenia takim scenariuszom wystarczyła obserwacja biegu spraw we wschodnich Niemczech. W austriackiej Socjalistycznej Partii Austrii (SPÖ) antykomunistycznym impregnatem okazała się filozoficzna i polityczna tradycja austromarksizmu ${ }^{58}$. Wśród socjalistów francuskich, działających pod nazwą Francuska Sekcja Międzynarodówki Robotniczej (SFIO), szalę na tę samą stronę przeważyła zręczna polityka przywódcy partii Leona Bluma (współpraca z komunistami - „tak”, zjednoczenie - „nie”). Ale już w Socjalistycznej Partii Włoch (PSI) spory o taktykę i kierunek polityki zakończyły się w 1947 r. kosztownym rozłamem; niezadowoleni z koncyliacyjnego wobec komunistów kursu lidera partii Pietro Nenniego secesjoniści pod przywództwem Giuseppe Saragata założyli konkurencyjną Partię Socjaldemokratyczną ${ }^{59}$.

Na tym tle dodatkowego wymiaru nabiera fenomen trzeciego wygranego na powojennej europejskiej scenie politycznej - chrześcijańskiej demokracji. W Wielkiej Brytanii, przy całej jej specyfice wyznaniowej oraz ugruntowanym systemie dwupartyjnym, z ponadklasowymi biegunami w postaci Partii Konserwatywnej i Partii Pracy, wspierającymi się od czasu do czasu na Partii Liberalnej, na partię chadecką nie było oczywiście miejsca. Jednakże w innych państwach europejskich wolnego pola dla ekspansji chrześcijańskiej demokracji znalazło się nadspodziewanie dużo.

56 A. Thorpe, A history of the British Labour Party, $3^{\text {rd }}$ ed., Palgrave MacMillan, London 2008, s. 8-35 i n.

57 Por. General Election of $5^{\text {th }}-19^{\text {th }}$ July 1945, w: General Election Results 1885-1979, www.election.demon. co.uk./geresults.html [dostęp 28.02.2016]; General Election of 23 ${ }^{\text {rd }}$ February 1950, w: ibidem; General Election of $25^{\text {th }}$ October 1951, w: ibidem.

58 J. Holzer, Europa zimnej wojny, Społeczny Instytut Wydawniczy Znak, Kraków 2012, s. 183-184; L. Kołakowski, Główne nurty marksizmu. Powstanie - rozwój - rozkład, wyd. 2 popr., Wydawnictwo Aneks, Londyn 1988, s. 555-558, 567-606.

59 R. Zariski, Problems and prospects of democrtaic socialism in France and Italy, „The Journal of Politics” 1956, Vol. 18, Nr 2, s. 254-280; J. Holzer, op.cit., s. 286. 
Trzeba przyznać, że na ogół potrafiła ona wykorzystać rysujące się szanse. Była to całkiem inna chadecja niż przed II wojną światową. W dużej mierze oczyszczona z prawicowości, klerykalizmu i konserwatyzmu ${ }^{60}$, często w nowych formach organizacyjnych, chętnie odwołująca się do katolicyzmu społecznego ${ }^{61}$, konsekwentnie centrowa, albo wychylona ku „lewemu centrum”, ciążąca ku współpracy z dawnymi wrogami: politycznym i gospodarczym liberalizmem oraz demokratycznym i reformistycznym socjalizmem. Krótko mówiąc: powojenne partie chadeckie, tak jak komuniści i socjaldemokraci, choć wychodziły z innych przesłanek, chciały nowego świata, w tym głębokich reform gospodarczych i socjalnych ${ }^{62}$.

Dzięki takiemu ukierunkowaniu europejscy chadecy szybko zaczęli sięgać po władzę albo współwładzę. Najsilniejszą i najtrwalszą pozycję uzyskali we Włoszech, RFN i Austrii, nie tylko dzięki talentom przywódców miejscowych partii chrześcijańsko-demokratycznych - Alcide de Gasperiego, Konrada Adenauera i Leopolda Figla, ale także m.in. wskutek podziału na włoskiej niekomunistycznej lewicy, niezdolności niemieckich socjaldemokratów do szerszego pozyskania warstw średnich oraz specyficznym regułom austriackiego systemu politycznego ${ }^{63}$. Przejściowa okazała się natomiast potęga chadecji francuskiej. Republikański Ruch Ludowy (MRP), partia premierów, ministrów i indywidualności miary Georgesa Bidaulta, Jeana Monneta czy Roberta Schumana, nie stała się wprawdzie pierwszą siłą polityczną Francji, ale równowaga wpływów z socjalistami i komunistami na parę lat zapewniła względną stabilność IV Republice, a samej MRP profity polityczne. Zaczęła przegrywać, gdy wyszła z rydwanu generała Charlesa de Gaulle’a, a ściślej, gdy ten w 1947 r. stworzył własną partię polityczną, konkurującą o podobny elektorat ${ }^{64}$.

Przesunięcia polityczne dokonujące się na Zachodzie Europy w pierwszych latach po wojnie wielce uprawdopodobniły wzrost interwencjonizmu państwowego

60 Wyjątkiem była Holandia, gdzie aż do 1980 r. nie doszło do zjednoczenia politycznego partii katolickiej i partii protestanckich. W rezultacie pozostały one po wojnie na pozycjach konfesyjnych i raczej zachowawczych. H.-M. Napel, The development of Dutch Christian Democracy, w: Christian democracy in the European Union [1945/1995]. Proceedings of the Leuven Colloquium 15-18 November 1995, Leuven University Press, Leuven 1997, s. 51, 52.

61 Inspiracją była tu raczej tradycja reformistyczna, skodyfikowana encykliką Rerum novarum Leona XIII z 1891 r., a nie późniejszy prokorporacyjny nurt poparty w encyklice Quadragesimo anno Piusa XI z 1931 r.

62 W. Becker, The emergence and development of christian democratic parties in Western Europe, w: Christian democracy in the European..., op.cit., s. 109-112.

63 Por. U. Lappeküper, Between concentration movement and people's party: The Christian Democratic Union in Germany, w: Christian democracy in Europe since 1945, Vol. 2, red. M. Gehler, W. Keiser, Routledge, London-New York 2004, s. 22-23; C. Masala, Born for government: The Democrazia Christiana in Italy, w: ibidem, s. 88-91; D.A. Binder, „Resciuing the Christian Occident” and „Europe in us”: The People's Party in Austria, w: ibidem, s. 121-123. O specyfice systemu politycznego w Austrii w dalszej części artykułu.

64 Zob. np. B. Béthouart, Entry for Catholics into the Republic: the Mouvement Républucain Populaire in France, w: ibidem, s. 74 i n. 
w gospodarce. Tak się bowiem składało, że wszyscy wygrani - komuniści, socjaldemokraci (socjaliści) i chadecy, niezależnie od dzielących ich fundamentalnych różnic, zgadzali się, że interwencjonizm należy zwiększać. Dla fundamentalistów liberalizmu ekonomicznego nadeszły prawdziwie ciężkie czasy. W porównaniu z okresem międzywojennym na wokandę szeroko wchodziły, oprócz wielu innych, postulaty nacjonalizacji, centralnego planowania, repartycji dochodu narodowego i uruchomienia wielkich programów socjalnych. Nowa gospodarka miała być mieszana, regulowana, bardziej egalitarna i opiekuńcza. Nie tylko komuniści, ale także socjaldemokraci i chrześcijańscy demokraci zawierali w swych enuncjacjach akcenty jednoznacznie antykapitalistyczne. Ustrój ten - czytamy np. w programie belgijskich socjalistów - „wszedł w fazę dekadencji” i powinien zostać zniesiony. Zaś ich chadeccy konkurenci deklarowali: „stary świat liberalny i kapitalistyczny jest w ruinie” i również nawoływali do budowy nowego systemu gospodarczego ${ }^{65}$. Dla wielu antyrewolucyjnych marksistów celem ostatecznym pozostawał socjalizm, oparty na własności społecznej lub państwowej oraz gospodarce planowej. Taki pożądany kierunek ewolucji ustrojowej wytyczała np. zachodnioniemiecka SPD ${ }^{66}$. Że „kapitalistyczny system gospodarczy nie zaspokoił żywotnych interesów państwowych i społecznych narodu niemieckiego" - przyznawała w programie z 1947 r. nawet Unia Chrześcijańsko-Demokratyczna (CDU), partia K. Adenauera i Ludwika Erhardta ${ }^{67}$.

W kwestii rozbudowy sektora państwowego w gospodarce zachodnie partie komunistyczne i socjaldemokratyczne (socjalistyczne) początkowo prezentowały dość zbliżone koncepcje. Zalecały na ogół upaństwowienie największych banków, przemysłu ciężkiego, części transportu i energetyki. Ta zadziwiająca zgodność wynikała $\mathrm{z}$ charakterystycznego dla lat bezpośrednio powojennych samoograniczenia postulatów własnościowych zachodnich komunistów, ostro kontrastującego z praktyką panującą w bloku wschodnim. Wraz z narastaniem zimnej wojny konsensus nacjonalizacyjny na zachodniej lewicy stopniowo odchodził w przeszłość. Co do chrześcijańskich demokratów, może sami z siebie nie lansowaliby prawodawstwa nacjonalizacyjnego (choć np. umiarkowaną etatyzację i strategiczne planowanie już tak), ale przez wzgląd na własne interesy wyborcze i koalicyjne skłonni byli udzielać mu poparcia, a czasem nawet inicjować ${ }^{6}$. Rzecz jasna, bliżej było im zawsze do socjaldemokratów (socjalistów) niż komunistów.

\footnotetext{
65 Cyt. za: J. Holzer, op.cit., s. 198.

66 Ibidem, s. 183.

67 Cyt. za: G. Therborn, Drogi do nowoczesnej Europy. Społeczeństwa europejskie w latach 1945-2000, tłum. Z. Pucek, Wydawnictwo Naukowe PWN, Warszawa-Kraków 1998, s. 46-47.

68 N.S. Timashoff, Nationalization in Europe and the catholic social doctrine, "The American Catholic Sociological Review” 1947, Vol. 8, Nr 2, s. 111-130.
} 
Tak czy inaczej, w drugiej połowie lat 40. XX w. wyglądało na to, że upaństwowienie największych kopalń, hut, przedsiębiorstw przemysłu przetwórczego, banków, spółek transportowych, firm ubezpieczeniowych itd., przy zachowaniu w rękach prywatnych mniejszych podmiotów gospodarczych, może stać się w Zachodniej Europie modelem uniwersalnym ${ }^{69}$.

\section{Nacjonalizacja w Austrii (1946-1947)}

Ustawy nacjonalizacyjne uchwalono w Austrii dwukrotnie: w lipcu 1946 r. i marcu 1947 r. Pierwsza ustawa miała wymiar wielogałęziowy, druga dotyczyła wyłącznie firm elektroenergetycznych. Ponadto dystrybuowała część przejętych praw własności z poziomu ogólnokrajowego na poziom krajów związkowych, jak również municypalny i komunalny. Po każdej z ustaw konieczne okazywały się jeszcze dopełniające dekrety i przepisy wykonawcze ${ }^{70}$.

Sumaryczny zasięg nacjonalizacji był bardzo duży. Upaństwowiono większość górnictwa (węgla, rud metali i ropy naftowej), przeważającą część przemysłu ciężkiego i chemicznego (kopalnie, huty, stalownie, wytwórnie maszyn, przetwórnie ropy, fabryki nawozów itd.), trzy kluczowe banki komercyjne, główne spółki elektroenergetyczne, kilka firm budowlano-remontowych oraz największe towarzystwo żeglugowe. Łącznie na własność państwa przeszło ponad 80 podmiotów gospodarczych, w tym około 70 z przemysłu o udziale w produkcji ogólnej rzędu 30\%. Były to najczęściej wielkie koncerny i przedsiębiorstwa wielozakładowe, co multiplikowało liczbę faktycznie upaństwowionych jednostek ${ }^{71}$.

O rozległej skali obu nacjonalizacji przesądziło ukierunkowanie ich przede wszystkim na własność III Rzeszy i jej obywateli, dominującą po 1938 r. w kluczowych dziedzinach austriackiej gospodarki. Wiele dużych firm zostało w części bądź w całości zetatyzowanych, względnie przekazanych prywatnym spółkom niemieckim

69 Por. M. Haynes, R. Husan, Market failure, state failure, institutions, and historical constraints in the East European transition, „Journal of European Area Studies” 2002, Vol. 10, Nr 1, s. 114; Ch.S. Maier, The two postwar eras and the conditions for stability in twentieth-century Western Europe. „The American Historical Review" 1981, Vol. 86, Nr 2, s. 331-332.

70 E. Langer, op.cit., s. 117, 118.

71 Por. The nationalisation of Austria's basic industries [The Federal Ministry of Transport and Nationalised Undertakings], „Annals of Collective Economy” 1952, Vol. 23, Nr 1, s. 4. 14-15, 21, 24-25, 30, 32, 35, 37-39; D. Stiefel, Fifty years of state-owned industry in Austria, 1946-1996, w: The rise..., op.cit., s. 237 i n.; A. Makać, op.cit., s. 145; K. Fiedor, Austria. Od gospodarki żarowej do Unii Europejskiej, Państwowy Instytut Naukowy - Instytut Śląski w Opolu, Opole 2000, s. 428-429. 
zaraz po Anschlussie, zaś w późniejszych latach państwo i biznes niemiecki prowadziły jeszcze inwestycje rozwojowe, zarówno modernizacyjne, jak i „na surowym korzeniu”. W 1944 r. udział kapitału niemieckiego na terenie byłej Austrii - według kryteriów granicznych sprzed Anschlussu - wynosił 96\% w przemyśle wydobywczym, $86 \%$ w całym przemyśle i $82 \%$ w bankowości ${ }^{72}$.

Po nacjonalizacji z lat 1946 i 1947 sektor państwowy teoretycznie powinien być jeszcze większy, gdyż poza własnością niemiecką włączono doń także mienie gospodarcze rodzimych kolaborantów, udziały obywateli austriackich w firmach niemieckich i kolaboranckich oraz należącą do zachodnich koncernów Vacuum Oil Company i Shell większościową część przemysłu naftowego (wydobycie i przerób). Przejęcie aktywów tych koncernów, posiadanych przez spółki anglo-amerykańskie, kanadyjskie i holenderskie, to jedyny przypadek nacjonalizacji własności nieniemieckiej i niekolaboranckiej ${ }^{73}$.

Austriacka nacjonalizacja przebiegała w bardzo specyficznych i niezbyt sprzyjających warunkach politycznych. Uchwalona została bowiem na długo przed formalnoprawną odbudową państwowości, a więc w sytuacji amerykańskiej, brytyjskiej, francuskiej i radzieckiej okupacji wojskowej. Automatycznie limitowało to swobodę decyzyjną i realizacyjną miejscowych organów władzy ${ }^{74}$. Na korzyść tych ostatnich zadziałały jednak dwie okoliczności. Po pierwsze, mocarstwa okupujące zdołały szybko uzgodnić zarówno powstanie ogólnoaustriackiego rządu (sierpień 1945 r.), jak i przeprowadzenie wyborów parlamentarnych (listopad 1945 r.). Po drugie, sprawująca od września 1945 r. kontrolę nad całością kraju, w tym austriacką legislacją, Rada Sojusznicza, władna sprzeciwić się w ciągu 30 dni każdej ustawie, skutecznie czynić to mogła tylko jednomyślnie. Wzrastające napięcie między ZSRR a mocarstwami zachodnimi sprawiło, że jedność w Radzie Sojuszniczej stała się trudno osiągalna. Tym samym, dzięki dysponowaniu rządem i parlamentem, strona austriacka mogła dość samodzielnie decydować o kształcie wewnętrznych rozwiązań prawnych ${ }^{75}$.

Pierwszy prowizoryczny rząd austriacki utworzono w kwietniu $1945 \mathrm{r}$. w zajętym przez Armię Czerwoną Wiedniu. W jego składzie, dość zrównoważonym politycznie,

72 K.W. Rotschild, Austria's economic development between two wars, Frederic Muller Ltd., London 1947, s. 80. Por. W. Grabska, Kapitał zachodnioniemiecki w gospodarce Austrii, w: W. Grabska, P. Landau, J. Zdanowicz, Szkice o gospodarce zachodnioeuropejskiej, PISM, Warszawa 1968, s. 20, 23.

73 A. Makać, op.cit., s. 147; J. Sikorski, op.cit., s. 174-175 (przyp. 7).

74 Wielka Brytania zajęła większość Tyrolu, Karyntię i Styrię, Francja - Vorarlberg i zachodni Tyrol, Stany Zjednoczone - Salzburg i Górną Austrię na południowym brzegu Dunaju, ZSRR - północną część Górnej Austrii, Dolną Austrię i Burgenland. Cztery sektory narodowe utworzono też w Wiedniu, dodatkowo wyodrębniając jeszcze dzielnicę okupowaną wspólnie.

75 R. Steininger, Austria, Germany and the cold war. From the Anschluss to the State Treaty 1938-1955, Berghahn Books, New York-Oxford 2008, s. 43-54. 
znaleźli się socjaliści, chadecy, komuniści i bezpartyjni. Funkcję kanclerza objął Karl Renner, wybitny przywódca SPÖ i teoretyk austromarksizmu. Ponieważ rządu tego, będącego jednostronną inicjatywą radziecką, nie uznały Stany Zjednoczone i Wielka Brytania, ani też żadne lokalne władze austriackie, w sierpniu 1945 r. poddano go rekonstrukcji, zmieniając nieco proporcje międzypartyjne i przyporządkowanie polityczne ministerstw. Kanclerzem pozostał K. Renner, Komunistyczna Partia Austrii (KPÖ) otrzymała trzy stanowiska ministerialne, rząd zaś jako całość zdobył akceptację na zewnątrz i wewnątrz Austrii ${ }^{76}$.

W listopadzie 1945 r. odbyły się wybory do Rady Narodowej i sejmów krajowych. Mimo trwającej okupacji były one w zasadzie demokratyczne i wolne ${ }^{77}$. Absolutną większość w Radzie Narodowej - 85 mandatów (49,7\% głosów) - zdobyła chrześcijańsko-demokratyczna Austriacka Partia Ludowa (ÖVP), socjaliści musieli zadowolić się 76 mandatami (44,5\% głosów), komunistom zaś przypadły tylko cztery (5,4\% głosów), co oznaczało druzgocącą klęskę ${ }^{78}$. Mogąc pokusić się o jednopartyjne rządy, zwycięska ÖVP postanowiła utrzymać koalicję z SPÖ, a nawet - przez wzgląd na stosunki z ZSRR - z KPÖ. Do nowego rządu weszło ośmiu chadeków, sześciu socjalistów i jeden komunista. Urząd kanclerza objął lider chadecji L. Figl, a wicekanclerzem został socjalista Adolf Schärf. Dotychczasowego kanclerza, K. Rennera, wybrano na prezydenta republiki (w grudniu 1945 r. ) $^{79}$.

Jeszcze przed wyborami ÖVP i SPÖ zawarły układ, w myśl którego „wszystkie stanowiska w państwie miały być obsadzane według proporcji wzajemnej siły obu partii”"80. W powiązaniu z wynikami wyborów (w $1945 \mathrm{r}$. i wielu późniejszych) zasada ta stała się podwaliną długoletnich rządów dwupartyjnych, niekiedy określanych

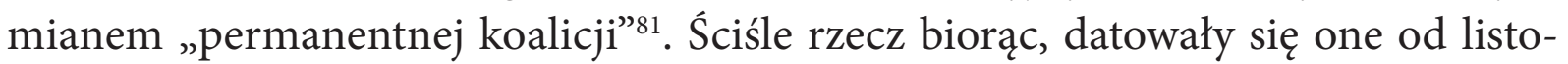
pada 1947 r., gdy z gabinetu L. Figla wycofał się reprezentant partii komunistycznej ${ }^{82}$.

76 W.B. Bader, Austria between East and West 1945-1955, Stanford University Press, Stanford, Cal. 1966, s. 27-28; W.C. Müller, Condemned the success: the 1945 transitional government in Austria, s. 5-8, https:// www.prio.org/global/upload/CSCW/Transitional_Governance/Muller.pdf [dostęp 14.03.2016].

77 Z udziału w wyborach wyłączono członków NSDAP, SA i SS.

78 W.C. Müller, op.cit., s. 13-15.

79 R. Steininger, op.cit., s. 73-76; E. Barker, Austria 1918-1972, University of Miami Press, Miami, Flo. 1973, s. 164-170. Wyboru prezydenta dokonały połączone izby parlamentu - Rada Krajowa (niższa) i Rada Federalna (wyższa).

80 H. Wereszycki, Historia Austrii, Zakład Narodowy im. Ossolińskich, Wrocław-Warszawa-Kraków-Gdańsk 1972, s. 338.

81 G. Smith, Życie polityczne w Europie Zachodniej, tłum. L. Dorn, Puls, Londyn 1992, s. 368. „Zasadą proporcji” (Proporzprincip) kierowały się wszystkie koalicje ÖVP i SPÖ aż do 1966 r. W szerszej perspektywie sprzyjała ona formalnej i nieformalnej implementacji mechanizmów neokorporacyjnych.

82 Bezpośrednim powodem dymisji komunistycznego ministra była deflacyjna reforma walutowa przeprowadzona 19 listopada 1947 r. KPÖ przyrównywała ją do „rabunku ludności” i „jarzma amerykańskiego”. J. Krasuski, Europa Zachodnia. Dzieje polityczne 1945-1993, Wydawnictwa Szkolne i Pedagogiczne, Warszawa 1995, s. 68-69. 
Obie ustawy nacjonalizacyjne uchwalono zatem w okresie koalicji rządowej chadeków i socjalistów z komunistami. Fakt ten miał o tyle istotne znaczenie, że ustawom przeciwstawiały się okupacyjne władze radzieckie ${ }^{83}$. Udział członka KPÖ w rządzie promującym i popierającym nacjonalizację stawiał austriackich zwolenników ZSRR w nieco trudniejszym położeniu, niż gdyby rodzimi komuniści pozostawali w jednoznacznej opozycji. Treść ustaw nacjonalizacyjnych wyrażała oczywiście wypośrodkowane stanowiska dwóch głównych partii - ÖVP i SPÖ ${ }^{84}$. Ciekawe, że znacznie więcej ustąpili posiadający większość w Radzie Narodowej chadecy; do tego stopnia, że ich reprezentacja parlamentarna zdecydowała się głosować „za” dopiero w ostatniej chwili. Spór z socjalistami, głównymi sprawcami legislacji, toczył się o to, czy państwo powinno przejąć także własność austriackich kolaborantów, czemu ÖVP długo się przeciwstawiała ${ }^{85}$. Komuniści, programowo domagający się znacjonalizowania niemal całej gospodarki nierolniczej, teraz jednak skonfudowani uczestnictwem w rządzie i własną słabością polityczną, ostatecznie głosowali za ustawami, choć nie życzył ich sobie ZSRR ${ }^{86}$.

Kontestowanie przez stronę radziecką prawodawstwa nacjonalizacyjnego może zakrawać na paradoks, ale w rzeczywistości wynikało z całkiem racjonalnych przesłanek. Ukierunkowanie nacjonalizacji przede wszystkim na własność niemiecką było bowiem $w$ istocie krokiem antyradzieckim, pomyślanym jako środek obronny przed masowymi demontażami, rekwizycjami i wywłaszczeniami uskutecznianymi na terenach okupowanych przez ZSRR. Ta zagrażająca austriackiemu potencjałowi gospodarczemu praktyka miała swoją genezę w ustaleniach poczdamskich o ściąganiu reparacji wojennych bezpośrednio $\mathrm{w}$ strefach okupacyjnych. W przypadku Austrii przewidziano, że konfiskacie na cele reparacyjne podlegać będą aktywa niemieckie. Mocarstwa zachodnie w swoich strefach korzystały z tego uprawnienia dość umiarkowanie, natomiast władze radzieckie wręcz przeciwnie, od początku stosowały maksymalnie szeroką interpretację pojęcia „aktywa niemieckie”, zawłaszczając także własność niemiecką pochodząca sprzed Anschlussu i sporo austriackiej, bynajmniej niekolaboranckiej ${ }^{87}$. Początkowo dokonywano przede wszystkim zaboru maszyn oraz innego ruchomego wyposażenia. W końcu czerwca 1946 r. administracja radziecka zaostrzyła swą politykę, przejmując w bezpośrednie władanie

\footnotetext{
83 E. Langer, op.cit., s. $115,119$.

84 Ibidem, s. 115-116.

85 J. Sikorski, op.cit., s. 174.

86 W.B. Bader, op.cit., s. 42; E. Barker, op.cit., s. 177-180.

87 Austria. Economic growth and government policy, www.countrystudies.us/Austria/84.htm [dostęp 12.10.2014]; G. Bischof, Allied plans and policies for the occupation of Austria 1938-1955, w: Austria in the twentieth century, red. R. Steininger, G. Bischof, M. Gehler, Transaction Publishers, New Brunswick, N.J.-London 2002, s. 176-177 [paginacja za wydaniem e-book z 2009 r. - J.L.].
} 
„252 zakłady przemysłowe, cały zastany tabor kolejowy i rzeczny, 160 tysięcy hektarów ziem uprawnych i niewielkie austriackie pola naftowe" 88 .

Zapobieżenie dalszym konfiskatom, nie tylko ze strony ZSRR, ale i mocarstw zachodnich, które potencjalnie mogły przecież zrewidować postępowanie, stanowiło najważniejszy cel ustaw nacjonalizacyjnych z lipca 1946 r. i marca 1947 r. Oficjalnie raczej się do tego nie przyznawano, eksponując w pierwszym rzędzie uwarunkowania ekonomiczne: unieruchomienie wielu zakładów z powodu nieobecności właścicieli, powojenny kryzys dostosowawczy, konieczności rekonstrukcyjne i rozwojowe, względy planowania gospodarczego itd. Wszystko to jednak były motywy poboczne, podobnie jak predylekcja socjalistów do sprawiedliwości społecznej i pełnego zatrudnienia. O czasie, trybie i zasięgu austriackiego prawodawstwa nacjonalizacyjnego w pierwszym rzędzie przesądziła potrzeba rozpięcia „parasola ochronnego” nad własnością zakwalifikowaną jako niemiecka bądź poniemiecka. Sprawę wielce ułatwiło posiadanie własnego rządu i parlamentu, jak również szeroki polityczny konsensus co do zasadności nacjonalizacji (partie ją inicjujące przyciągały grubo ponad $90 \%$ elektoratu $)^{89}$. Znamienne, że przy konstruowaniu obu ustaw niemal nie odwoływano się do doświadczeń przedwojennych oraz literalnej treści programów SPÖ i ÖVP. W szczególności zwracało uwagę pominięcie postulatów odnoszących się do demokracji robotniczej, rozwijanych szeroko m.in. przez głównego ideologa austromarksizmu, Otto Bauera ${ }^{90}$.

Ze względu na fakt, że austriackiej nacjonalizacji podlegała niemal wyłącznie własność III Rzeszy, jej obywateli i miejscowych kolaborantów, całą operację przeprowadzono w zasadzie bez odszkodowania. Jednak w latach późniejszych rekompensaty częściowo wypłacono, przede wszystkim własnym obywatelom, w znacznie mniejszym stopniu kapitałowi niemieckiemu. Pierwszą sprawę regulowały ustawy z lat 1954 i 1959, drugą porozumienie z rządem RFN z 1957 r. ${ }^{91}$

88 J. Rydel, Okupacja Austrii, w: Najnowsza historia świata 1945-1995, t. 1, 1945-1963, red. A. Patek, J. Rydel, J.J. Węc, Wydawnictwo Literackie, Kraków 1997, s. 50. Zob. też D. Horváth, Austria - balance at the time of cold war, s. 4, www.coldwar.hu/html/en/conferences/Other_conferences/Dora_Horvath.pdf [dostęp 14.03.2016].

89 Na temat motywacji towarzyszących austriackim nacjonalizacjom por. E. Langer, op.cit., s. 115, 116-117, 146; B. Unger, K. Heitzmann, The Austrian „AlpenModel” - back to Bismarck?, s. 5, www.2.econ. uu.nl/users/unger/publications/ungerheitzmann11.pdf [dostęp 15.10.2014]; The nationalisation of Austria..., op.cit., s. 2, 3-4, 14; J. Sikorski, op.cit., s. 175, 179-180; K. Fiedor, op.cit., s. 427 i n.

90 E. Langer, op.cit., s. 141, 151; K.L. Shell, The transformation of Austrian socialism, New York, N.Y. 1962, s. 206-207. Przedstawiciele robotników zasiadali jedynie w parytetowych radach konsultujących kwestie zatrudnienia i zabezpieczeń socjalnych. Partycypacja robotnicza w zyskach i zarządzaniu pojawiła się w austriackim sektorze państwowym dopiero po 1955 r. The nationalisation of Austria..., op.cit., s. 8-9; E. Langer, op.cit., s. 116.

91 Ibidem, s. 116, 118, 119-121; Austria. Economic..., op.cit., [bez paginacji]; W. Grabska, op.cit., s. 27-31. 
W międzyczasie odszkodowania uzyskały również koncerny naftowe Vacuum Oil Company oraz Shell ${ }^{92}$.

Znacjonalizowanie w $1946 \mathrm{r}$. ich austriackich aktywów oficjalnie tłumaczono dużymi zniszczeniami pól naftowych i rafinerii w końcowej fazie II wojny światowej, faktycznie zaś stała za tym ówczesna geografia polityczna. Złoża ropy naftowej i zakłady ją przetwarzające umiejscowione były w większości w radzieckiej strefie okupacyjnej. Chodziło więc o zabezpieczenie w tej dziedzinie austriackiej gestii własnościowej na okoliczność przyszłego zakończenia okupacji. Nacjonalizacja majątków obu koncernów miała w danym momencie wymiar wyłącznie nominalny, gdyż praktyczna egzekucja pozostawała poza możliwościami władz austriackich. Zakłady wchodzące w skład Vacuum Oil Company i Shell jeszcze przed 1946 r. przekształcone zostały w fikcyjne spółki akcyjne i połączone w jeden wydobywczo-rafineryjny „holding” naftowy, całkowicie podporządkowany radzieckiej administracji ${ }^{93}$.

ZSRR nie dopuścił też na kontrolowanym przez siebie obszarze do wykonania postanowień o nacjonalizacji własności poniemieckiej i pokolaboranckiej. Postąpiono z nią podobnie jak z majątkiem koncernów Vacuum Oil Company i Shell. W rezultacie w domenie radzieckich władz okupacyjnych, poza "holdingiem” naftowym, znalazły się jeszcze bliźniaczy „holding” wszystkich pozostałych spółek przemysłowych oraz kilka odrębnych towarzystw akcyjnych o profilu handlowym i transportowym ${ }^{94}$. Po 1955 r. cały ów stan posiadania przeszedł w ręce państwa austriackiego. Mimo że zwracane obiekty były na ogół w „słabej kondycji”, transfer obwarowano odszkodowaniami, głównie w surowcach i materiałach, w mniejszym stopniu w pieniądzu. W zamian za odzyskane mienie Austria wypłaciła ZSRR ogółem około $150 \mathrm{mln}$ USD i dostarczyła $10 \mathrm{mln} \mathrm{t}$ ropy naftowej (a uiszczała też zapłatę w węglu) ${ }^{95}$.

Opóźniona na części terytorium niemal o dekadę w stosunku do litery prawodawstwa praktyka realizacyjna to jeszcze jedna - obok braku państwowości i antyradzieckiej genezy - specyfika austriackiej nacjonalizacji. $Z$ tego powodu tamtejszy sektor państwowy, po ustawach z lat 1946 i 1947 formalnie rzecz biorąc relatywnie największy w kapitalistycznej Europie ${ }^{96}$, pod względem zakresu realnego długo nie dorównywał nominalnemu. Do połowy lat 50. władze austriackie dysponowały tylko około połową majątku gospodarczego objętego aktami nacjonalizacyjnymi ${ }^{97}$.

\footnotetext{
92 A. Makać, op.cit, s. 147.

93 J. Sikorski, op.cit., s. 175, 189; Oil and gas in Austria, www.viennabasin.spe.org/aboutus/whatisspevbs/oilandgasinaustria.pdf [dostęp 10.03.2016].

94 Szerzej zob. W.B. Bader, op.cit., s. 110-131.

95 Por. E. Langer, op.cit., s. 119, 120; The nationalization of Austria.., op.cit., s. 2; Austria. Economic..., op.cit., [bez paginacji]; J. Rydel, Traktat pokojowy z Austria, w: Najnowsza historia..., op.cit., s. 211.

96 J. Zawadzki, Kapitalizm współczesny. Szkice ekonomiczne, wyd. 2 zm., PWE, Warszawa 1967, s. 242.

97 The nationalization of Austria..., op.cit., s. 4, 39.
} 
System zarządzania zetatyzowaną częścią gospodarki był, jak na standardy kapitalistyczne, silnie scentralizowany i dyrektywny. Znacjonalizowane banki zachowały status spółek akcyjnych, ale dość ściśle podlegały Związkowemu Ministerstwu Finansów ${ }^{98}$. Podobnie potraktowano przedsiębiorstwa $\mathrm{z}$ innych dziedzin gospodarki, z tą różnicą, że upaństwowione w 1946 r. podporządkowano Związkowemu Ministerstwu Rezerw i Planowania Gospodarczego, a upaństwowione w 1947 r. - Związkowemu Ministerstwu Energetyki. W górnictwie węglowym, hutnictwie żelaza i stali oraz elektroenergetyce dodatkowo ustanowiono pośrednie państwowe struktury integrujące. W dwóch pierwszych branżach zdecydowano się na holdingi powiernicze, zaś w elektroenergetyce na ogólnogałęziową spółkę akcyjną o organizacji przypominającej brytyjskie korporacje publiczne, jednak znacznie mniejszej autonomii. Na każdym szczeblu domeny państwowej starano się przestrzegać parytetów międzypartyjnych ${ }^{99}$.

Zasady funkcjonowania austriackiego sektora państwowego, w kolejnych latach poszerzanego już drogą etatyzacji, ulegały licznym modyfikacjom. Do pierwszej doszło w końcu 1949 r., kiedy to wszystkie uprzednio znacjonalizowane podmioty gospodarcze - z wyjątkiem banków - przekazano w gestię nowo utworzonego Związkowego Ministerstwa Transportu, Łączności i Przedsiębiorstw Znacjonalizowanych. W następnym okresie, jeśli nie liczyć bankowości, w sektorze zetatyzowanym wzmagały się raczej tendencje centralizacyjne i konsolidacyjne. Wynikało to m.in. z ewolucji układu politycznego. Do 1949 r. w polityce wobec państwowej własności więcej do powiedzenia mieli proautonomicznie nastawieni do niej chadecy, z ministrem rezerw i planowania gospodarczego, Peterem Kraulandem, na czele. Od końca lat 40. stopniowo wzmacniały się wpływy socjalistów, opowiadających się za bardziej bezpośrednim zarządzaniem. Symbolem tej fazy stała się polityka Karla Waldbrunnera, szefa resortu transportu, łączności i przedsiębiorstw znacjonalizowanych (tzw. Waldbrunner Regime) ${ }^{100}$.

\section{Nacjonalizacja we Francji (1944-1946)}

Prawodawstwo nacjonalizacyjne we Francji było w analizowanym okresie dość obfite. Składało się nań blisko dwadzieścia aktów prawnych, nie tylko rangi ustawowej,

\footnotetext{
98 J. Sikorski, op.cit., s. 178.

99 Ibidem, s. 180-189.

100 E. Langer, op.cit., s. 116, 121-124; K.L. Shell, op.cit., s. 205, 207 i n.
} 
ale także dekretów z mocą ustaw ${ }^{101}$. Uderza dość wąski zakres przedmiotowy kolejnych posunięć nacjonalizacyjnych, zwykle zamykający się w obrębie jednej gałęzi czy branży, a niekiedy po prostu „punktowy”, tj. dotyczący pojedynczych podmiotów gospodarczych.

Nacjonalizacja francuska trwała półtora roku: rozpoczęła się jeszcze w trakcie działań wojennych w grudniu 1944 r., a zakończyła w czerwcu 1946 r. W czasie, gdy na czele rządów tymczasowych stał generał Ch. de Gaulle (wrzesień 1944 r. - styczeń 1946 r.), znacjonalizowane zostały: kopalnie węgla w zagłębiach Nord i Pas-de-Calais (grudzień 1944 r.) 102; niektóre firmy należące do kolaborantów, m.in. zakłady Renault (styczeń 1945 r.); pozostałości przemysłu lotniczego, od 1937 r. w większości już państwowego (maj 1945 r.); parę przedsiębiorstw transportu lotniczego (czerwiec 1945 r.); zaś po wyborach do pierwszego Narodowego Zgromadzenia Konstytucyjnego - Bank Francji i cztery największe banki komercyjne (grudzień 1945 r.). Dalsze nacjonalizacje stanowiły już dorobek gabinetu socjalisty Féliksa Gouina (styczeńczerwiec 1946 r.). Państwo przejęło wówczas elektroenergetykę, gazownictwo i 34 towarzystw ubezpieczeniowych (kwiecień 1946 r.), Bank Algierii i górnictwo węglowe (maj 1946r.) oraz - na krótko przed odejściem rządu F. Gouina - zakłady poligraficzne Sociéte Nationale des Enterprises de Presse (czerwiec 1946 r.) ${ }^{103}$. Francuskiej nacjonalizacji, z wyjątkiem aktów o charakterze represyjnym (których było tylko kilka), towarzyszyło z zasady pełne odszkodowanie dla dotychczasowych właścicieli.

Zwraca uwagę, że nacjonalizację realizowano w warunkach swoistego prowizorium ustrojowego. Kwestię nowej konstytucji ostatecznie rozstrzygnięto dopiero w październiku 1946r. (drugie referendum konstytucyjne); od tego też czasu formalnie zaistniała IV Republika. Do późnej jesieni 1945 r. nie było nawet parlamentu, dlatego Rząd Tymczasowy nie tylko odpowiadał za egzekutywę, ale wypełniał także funkcje prawodawcze, posługując się dekretami z mocą ustaw. W takim właśnie trybie ogłaszano pierwsze akty nacjonalizacyjne. Uległo to zmianie po wyborach do Narodowego Zgromadzenia Konstytucyjnego w październiku 1945 r. Ostatnią "dekretową" nacjonalizację, dotyczącą części transportu lotniczego, przeprowadzono w czerwcu

101 K. Katzarov, op.cit., s. 44-45.

102 Nacjonalizację, przeprowadzoną w trybie prowizorycznym, wymusiła sytuacja panująca w obu zagłębiach. Zrewoltowani i uzbrojeni górnicy przystąpili bowiem do okupacji tamtejszych kopalni, aby z jednej strony chronić je przed zniszczeniem przez wycofujących się Niemców, a z drugiej nie dopuścić do powrotu dawnych właścicieli. Słowem, zaczęła się „dzika” socjalizacja. Szybkie znacjonalizowanie miejscowych kopalni skutecznie zaradziło temu niebezpieczeństwu.

103 Por. Les nationalisations de la libération. De l'utopie au compromis, red. C. Andrieu, L. Le Van, A. Prost, Presses de la Fondation Nationale des Sciences Politiques, Paris 1987, rozdz. XIX-XXIII; F. Chadeau, The rise and decline of stated-owned industry in twentieth-century France, w: The rise..., op.cit., s. 189-190; A. Makać, op.cit., s. 94-95; A. Wieczorkiewicz, op.cit., s. 101-102. 
1945 r. Poczynając od grudniowej nacjonalizacji w sektorze bankowym, dokonywano jej już zawsze w drodze ustawowej, choć ciągle przy braku konstytucji ${ }^{104}$.

Bezpośrednio po wojnie na francuskiej scenie politycznej, nie licząc generała Ch. de Gaulle'a i jego otoczenia, kluczowe role odgrywały trzy nurty polityczne: komuniści, socjaliści oraz chrześcijańscy demokraci. Odzwierciedlało się to już w okresie Rządu Tymczasowego, ale formalną podstawę dla tej sytuacji stworzyły dopiero wyniki wyborów parlamentarnych w październiku 1945 r. Najwięcej głosów - 26\% - padło na Francuską Partię Komunistyczną (PCF), ale socjalistyczna SFIO i chadecka MRP uzyskały niewiele mniejsze poparcie, w obu przypadkach wyraźnie przekraczające $20 \%$. W sumie można więc było mówić o remisie. Traktowane łącznie, trzy główne partie przyciągnęły 75\% elektoratu. Brak wyraźnego zwycięzcy i autorytet Ch. de Gaulle’a, który pozostał premierem, sprawiły, że trójkoalicja okazała się najlepszym rozwiązaniem. W nowym rządzie każda z partii miała po pięciu przedstawicieli i po jednym wicepremierze ${ }^{105}$.

Koalicja PCF, SFIO i MRP, powielona później w rządzie F. Gouina i utrwalona przez kolejne wybory w czerwcu 1946 r. ${ }^{106}$, nie tylko stabilizowała układ rządzenia, ale przesądziła też o wdrażaniu polityki nacjonalizacyjnej. Tak się bowiem składało, że komuniści, socjaliści i chadecy, jakkolwiek poważnie różnili się w kwestiach szczegółowych, co do zasady jednoznacznie popierali nacjonalizację. Obie partie lewicowe kontynuowały tu długoletnią tradycję, w sferze koncepcyjnej jeszcze XIX-wieczną ${ }^{107}$, w sferze praktycznej z lat 1936-1937, kiedy SFIO współtworzyła, a PCF firmowała pierwszy rząd Frontu Ludowego L. Bluma ${ }^{108}$. Francuscy chrześcijańscy demokraci,

104 Pierwotnie konstytucję uchwalono w kwietniu 1946 r., ale zaraz przepadła w referendum. Powiodło się natomiast drugie podejście: we wrześniu 1946 r. przegłosowanie w Narodowym Zgromadzeniu Konstytucyjnym, w październiku tego samego roku przyjęcie w referendum (większością 53\%). D. Nohlen, P. Stöver, op.cit., s. 674,684 .

105 Ibidem, s. 688; J. Krasuski, op.cit., s. 30-31. W składzie rządu znalazło się jeszcze po jednym przedstawicielu radykałów i prawicy, dwóch reprezentantów ruchu oporu oraz dwóch bezpartyjnych.

106 Trójpartyjny sojusz polityczny, uskuteczniany już wcześniej, formalnie zawarto w styczniu 1946 r., krótko po odejściu ze stanowiska premiera generała Ch. de Gaulle’a. M. Morabito, D. Bourmand, Historia konstytucyjna i polityczna Francji (1789-1958), tłum. A. Jamróz, Temida 2, Białystok 1996, s. 510. W wyborach czerwcowych 1946 r. na PCF ponownie padło 26\%, ale na MPR tym razem 28\%, zaś na SFIO - $21 \%$ głosów. W rezultacie nowym premierem został G. Bidault, lider MRP. D. Nohlen, P. Stöver, op.cit., s. 689.

107 Wczesne postulaty nacjonalizacyjne i etatyzacyjne rozmaitych nurtów francuskiego socjalizmu omawia m.in. J.P. Machelon, L'idée de nationalisation en France de 1840 à 1914, w: Administration et contrôle de l'économie: 1800-1914, [M. Bruguiere et al.], Librairie Droz, Genève 1985, s. 1-64. W wersjach bardziej umiarkowanych wysuwały je również inne opcje ideowe i polityczne, w tym liberałowie. To z ich kręgów wyszedł w 1836 r. chronologicznie pierwszy projekt nacjonalizacji, autorstwa Nicolasa Martin du Norda i dotyczący kolejnictwa. W przyszłości nacjonalizację kolei politycy liberalni proponowali jeszcze kilkakrotnie. W $1878 \mathrm{r}$. za rządu Julesa Defaure’a państwo wykupiło z rąk prywatnych pierwsze 2,5 tys. linii kolejowych.

108 W środowisku SFIO rozwijana była w latach 30., np. przez Julesa Mocha, koncepcja nacjonalizacji tzw. uprzemysławiającej, obejmującej kluczowe gałęzie przemysłu i służącej podniesieniu ogólnego poziomu industrializacji w powiązaniu z naprawą stosunków pracy. Praktyka nacjonalizacyjna z lat 1936-1937 okazała 
reprezentowani po wojnie przez MRP, flirt z nacjonalizacją zaczęli stosunkowo niedawno. Inspirację stanowiła tradycja katolicyzmu społecznego, silnie akcentująca społeczne obowiązki własności prywatnej oraz podległość jej interesów wobec kategorii dobra ogólnego ${ }^{109}$. W rezultacie MRP wspierała nacjonalizację wszędzie tam, gdzie jej zdaniem wielki biznes ubezwłasnowolniał administrację centralną i lokalną, gdzie zagrażał niezależności finansowej państwa, gdzie wydobywał i przetwarzał surowce strategiczne, wreszcie tam, gdzie inicjatywa prywatna nie funkcjonowała bądź nie osiągała zysków, a dana dziedzina gospodarki zaspokajała istotne potrzeby społeczne $e^{110}$.

Jeśli zaś pamiętać, że podobnie myślało wiele osobistości z niekomunistycznego ruchu oporu oraz otoczenia przywódcy Wolnej Francji, jak również sam generał Ch. de Gaulle, zmierzający do „wyciszenia” komunistów „przez dopuszczenie ich do władzy, przy jednoczesnym przyjmowaniu najbardziej nośnych postulatów ich programu [...]"111, stanie się jasne, że w kwestii nacjonalizacji nie zadawano pytania „czy?”, ale „jak?”. Na początku marca 1945 r. generał Ch. de Gaulle, już jako premier Rządu Tymczasowego, mówił: „Jest zadaniem państwa przejęcie na własność zaopatrzenia w energię w jej najważniejszych formach (węgiel, elektryczność, ropę naftową), najważniejszych środków komunikacji (kolejnictwo, flotę, lotnictwo) oraz instrumentów obrotu pieniężnego, od których są one zależne" ${ }^{112}$. Według dawno wypowiedzianej, ale celnej oceny, nacjonalizacja stała się we Francji „kamieniem probierczym nowej moralności i nowej demokracji"113.

Fakt, że o przeprowadzeniu nacjonalizacji zadecydował powojenny układ sił politycznych, nie oznaczał, że motywacje partii współrządzących były tej samej natury. W MRP i części SFIO wyraźnie dominowały bowiem kalkulacje ekonomiczne. Nacjonalizację uznawano za nieodzowny warunek powojennej odbudowy, rekonstrukcji i modernizacji gospodarki. Wymagało to dużych inwestycji, trudnych do finansowego uniesienia dla inicjatywy prywatnej, z uwagi na deficytowość oraz rozdrobnienie

się o wiele skromniejsza (przemysł lotniczy, niektóre fabryki zbrojeniowe, część kolejnictwa). W jeszcze większym stopniu odbiegała od programu PCF, docelowo zorientowanego na upaństwowienie niemal całej gospodarki. Por. É. Méchoulan, Jules Moch un socialiste d'érangeant, Emile Bruylant, Bruxelles-Paris 2000, s. 67-69; E. Chadeau, op.cit., s. 186-188.

109 J.B. Duroselle, Początki katolicyzmu społecznego we Francji 1822-1870, tłum. Z. Jakimiak, Instytut Wydawniczy Pax, Warszawa 1961, passim.

110 I. Woloch, Left, right and centre: the MRP and the post-war moment, „French History” 2007, Vol. 21, $\mathrm{Nr} 1$, s. 85-106; The Programme of the M.R.P., [23 ${ }^{\text {rd }}$ March 1946; bez paginacji], www.archive.thetablet. co.uk./article/23 rd-march-1946/6/Programme-of-the-mrp.pdf [dostęp 4.03.2016].

111 Cyt. za: Ch. Williams, Charles de Gaulle. Ostatni wielki Francuz, tłum. A. Chajewski, Amber, Warszawa 2007, s. 275.

112 Cyt. za J. Holzer, op.cit., s. 98.

113 M. Einaudi, M. Bye, E. Rossi, Nationalization: French and Italian experiences, Cornell University Press, Ithaca, N.Y. 1955, s. 7. 
niektórych dziedzin wytwórczości i usług. Państwo, jak sądzono, miało tu znacznie większe możliwości mobilizacyjne i realizacyjne ${ }^{114}$. Zarazem poczynania nacjonalizacyjne wpisywano w perspektywę szerszą, związaną z próbami ukierunkowywania gospodarki francuskiej na indykatywne planowanie centralne. Stąd w styczniu 1946 r. powołano Generalny Komisariat ds. Planowania, Wyposażenia i Modernizacji Gospodarki. Na jego czele stanął J. Monnet; po roku jego urząd dysponował już strategicznym planem rozwojowym na lata 1947-1950. W tym kontekście przeprowadzenie każdej następnej nacjonalizacji traktowano jako zabezpieczanie pola do realizowania zamierzeń planistycznych. W późniejszych latach ogłaszano kolejne plany, a gospodarkę francuską, nie tylko przez wzgląd na tę praktykę, ale i inne formy państwowego interwencjonizmu, coraz częściej określano mianem dirigisme ${ }^{115}$.

Najbardziej politycznie i ideologicznie podchodzili do kwestii nacjonalizacji komuniści. Przede wszystkim zmierzali do poszerzenia nacjonalizacji poza pakiet akceptowany przez gaullistów oraz wspierający ich na ogół MRP. Mogli tu liczyć na poparcie dużej części SFIO, choć zwykle nie jego kierownictwa. Jeszcze przed wyłonieniem pierwszego parlamentu PCF dwukrotnie bez powodzenia przedkładała propozycje znacjonalizowania przemysłu żelaza i stali ${ }^{116}$. W listopadzie $1945 \mathrm{r}$. opracowała, wspólnie z innymi partiami robotniczymi, tzw. Program Lewicy. Podkreślał on konieczność nacjonalizacji całego górnictwa (nie tylko węglowego, także rud żelaza i metali niezależnych), hutnictwa (żelaza, stali, aluminium itd.), transportu (łącznie z flotą handlową), elektroenergetyki i gazownictwa, przemysłu chemicznego i naftowego, banków i ubezpieczeń, handlu zagranicznego ${ }^{117}$. Wykraczało to znacznie poza pole kompromisu możliwe do przyjęcia dla gaullistów, MRP i umiarkowaną część SFIO. Ponieważ jednak wśród socjalistów przeważała opcja „przyspieszenia" nacjonalizacyjnego, komuniści mieli realną szansę. W tej sytuacji w grudniu 1945 r. głos zabrało Narodowe Zgromadzenie Konstytucyjne, uchwalając program nacjonalizacji ograniczony do górnictwa węglowego, hutnictwa, elektroenergetyki,

114 Por. P. Dumontier, C. Lavrin, The financial impact of the French government nationalization/privatization strategy, October $4^{\text {th }}$ 2001, s. 6, www.affi.asso.fr/uploads/Externe/0d/CTR_FICHIER_26_1226069122. pdf [dostęp 8.10.2014]; D. Barjot, op.cit., s. 1.

115 Por. B.M. Rowland, Gaullist economic policies: the role of indicative planning, w: Charles de Gaulle's legacy of ideas, red. B.M. Rowland, The Washington Foundation for European Studies, Washington, D.C. 2011, s. 23-32; Ch.P. Kindleberger, French planning, National Bureau of Economic Research, s. 279-290, www.nber.org/chapters/c1426.pdf [dostęp 16.10.2014]. W pierwszych latach po wojnie we Francji rozbudowano też znacznie politykę społeczną. Między innymi zwiększono emerytury i zasiłki dla bezrobotnych, wprowadzono zasiłki rodzinne i powrócono do 40-godzinnego tygodnia pracy.

116 F. Godelier, Usinor and the French steel industry: from "private” monopoly to "public" competitor, 1948-2001, „Business and Economic History” 2006, Vol. 4, s. 4, [on-line], http://www.thebhc.org./BEH/ 06/godelier.pdf [dostęp 11.10.2014].

117 A. Makać, op.cit., s. 92. 
transportu, przemysłu chemicznego i bankowości ${ }^{118}$. Było to więcej niż przewidywał dotąd rząd, ale mniej niż postulowali komuniści. Większość elementów z tego pakietu zrealizowano w okresie rządu F. Gouina.

Istniała możliwość, że na tym się nie skończy. W styczniu 1946 r. PCF udało się porozumieć z SFIO w sprawie wspólnego projektu nowej konstytucji. Choć nie został skonsultowany na szczeblu rządowym, obie partie zdecydowały się przedłożyć go Narodowemu Zgromadzeniu Konstytucyjnemu. Projekt uznawał prawo państwa do ustawowego regulowania zasięgu własności prywatnej, zapowiadając od razu, że dziedziny o charakterze „służby publicznej” lub „faktycznego monopolu” powinny stać się własnością zbiorową (czytaj: państwową). Otwierało to drogę do daleko idącego pogłębienia nacjonalizacji w duchu raczej Programu Lewicy niż grudniowego stanowiska Konstytuanty ${ }^{119}$. Współkoalicjant partii komunistycznej i socjalistycznej, chadecka MRP, podobnie jak opozycja prawicowa, zareagowała bardzo ostro. Szermowała m.in. zarzutem, że wejście w życie konstytucji o tak szeroko zakreślonym zasięgu gospodarki państwowej umożliwiłoby „sowietyzację” Francji ${ }^{120}$.

Odrzucenie, po uchwaleniu w Narodowym Zgromadzeniu Konstytucyjnym, inkryminowanego projektu konstytucji w referendum w maju $1946 \mathrm{r}$. na chwilę zdezaktualizowało ów zarzut. Jednakże drugi projekt konstytucji perspektywę zmian własnościowych kreślił niemal równie radykalnie, podtrzymując postulaty nacjonalizacyjne w przypadku sytuacji zarówno „służby publicznej”, jak i „faktycznego monopolu"121. MRP nie wyciągnął tym razem straszaka "sowietyzacji”. Przeciwnie, opowiedział się za nowym projektem. W sporze z komunistami i socjalistami nie chodziło bowiem o nacjonalizację, ale o strukturę i kompetencje organów władzy politycznej. W tej sferze kompromis międzypartyjny okazał się możliwy (choć kontestował go Ch. de Gaulle), zapisy nacjonalizacyjne to cena zapłacona przez MRP za jego zawarcie.

Miesiąc po zaakceptowaniu w referendum drugiego projektu konstytucji odbyły się kolejne wybory parlamentarne (listopad 1946r.). Pierwszą pozycję odzyskali komuniści (ponad 28\% głosów), podczas gdy MRP (ponad 25\%) i zwłaszcza SFIO (poniżej 17\%) straciły po kilka punktów procentowych ${ }^{122}$. Mimo to na czele koalicji rządowej stanął socjalista L. Blum, a innego przedstawiciela tej partii - Vincenta Auriola - obrano prezydentem. Uzgadnianie wspólnych działań między PCF, MRP

\footnotetext{
118 Ibidem.

119 J. Baszkiewicz, Historia Francji, Zakład Narodowy im. Ossolińskich, Wrocław-Warszawa-Kraków-Gdańsk 1974, s. 702-703.

120 J. Krasucki, op.cit., s. 31-32.

121 J. Baszkiewicz, op.cit., s. 703.

122 D. Nohlen, P. Stöver, op.cit., s. 690.
} 
i SFIO przychodziło już wówczas z coraz większym trudem. Do głównych punktów spornych należały: żądania podwyżek płac, polityka kolonialna, stosunek do ZSRR, uczestnictwo w planie Marshalla.

W tym czasie MRP zaczęła stopniowo rewidować stanowisko co do dalszej nacjonalizacji (m.in. wskutek licznych strajków w sektorze państwowym). Komunistyczne plany w tym zakresie ostatecznie upadły, gdy na przełomie kwietnia i maja $1947 \mathrm{r}$. reprezentujący PCF ministrowie najpierw sprokurowali kryzys rządowy, a następnie utracili stanowiska na mocy dekretu prezydenta V. Auriola ${ }^{123}$. Oznaczało to upadek trójkoalicji. Odtąd aż do prezydentury François Mitteranda przez kilka dziesięcioleci nie było ani komunistów w rządzie, ani żadnej nowej nacjonalizacji.

Zmiana sytuacji politycznej wpłynęła też na stosunki wewnętrzne we francuskim przemyśle. Od lutego $1945 \mathrm{r}$. w przedsiębiorstwach zatrudniających ponad 50 pracowników robotnicy i personel techniczny mogli wybierać komitety zakładowe, uprawnione do kierowania działalnością socjalną oraz konsultowania kwestii produkcyjnych (organizacja, wyniki itp.). Formalnie rzecz biorąc, dotyczyło to całości przemysłu, niezależnie od typu własności, w praktyce jednak komitety zakładowe najlepiej rozwijały się w sektorze państwowym. W firmach prywatnych ich znaczenie już w 1946 r. skutecznie osłabiła kontrakcja ze strony związków pracodawców, zjednoczonych w Krajową Radę Patronatu Francuskiego ${ }^{124}$. Zahamowanie procesów nacjonalizacyjnych wiosną 1947 r. przesądziło więc zarazem o dość ograniczonej w stosunku do pierwotnych zamierzeń demokratyzacji stosunków pracy ${ }^{125}$.

Nacjonalizacja przyniosła natomiast widoczny efekt konsolidacyjno-koncentracyjny. W zdecydowanej większości przypadków przejęte firmy przekazano bowiem w gestię nowo powstałych ogólnogałęziowych państwowych quasi-koncernów. Dla przykładu: Électricité de France, działająca od kwietnia 1946r., miała pod sobą 86 elektrowni cieplnych, 300 hydroelektrowni i 1150 stacji przesyłowych należących dotąd do - odpowiednio - 54, 100 i 708 firm prywatnych ${ }^{126}$. Pojedyncze firmy państwowe początkowo zachowywały dużą autonomię względem władz zwierzchnich, podlegając

123 Na czele rządu SFIO, PCF i MRP stał wówczas socjalista Paul Ramadier. Bezpośrednią przyczyną dymisji ministrów komunistycznych stały się rozbieżności w kwestii polityki płacowej. Żądania podwyżek płac formułowano w toku masowych strajków robotniczych (m.in. w znacjonalizowanych zakładach Renault). Głębszym podłożem rozpadu trójkoalicji było narastanie zimnej wojny. Dotychczasowi partnerzy PCF nie życzyli sobie już z nią dalszej koalicji (na to samo naciskali szermujący perspektywą planu Marshalla Amerykanie), a sami komuniści pod wpływem Moskwy także przeszli do znacznie ostrzejszej linii politycznej.

124 A. Prost, Zarys historii Francji w XX wieku, tłum. J. Błońska, Universitas, Kraków 1997, s. 70; J. Baszkiewicz, op.cit., s. 696, 707-708.

125 E. Chadeau, op.cit., s. 200-201.

126 D. Barjot, op.cit., s. 1-2, 10-12. W przypadku stacji przesyłowych nie była to pełna własność prywatna, ale użytkowanie na mocy koncesji udzielanych przez władze lokalne. Szerzej na temat centralizacyjnych aspektów nacjonalizacji francuskich zob. A. Wieczorkiewicz, op.cit., s. 102-107. 
jedynie kontroli ex post. Zarząd nad nimi objęly rady administracyjne składające się $\mathrm{z}$ reprezentantów państwa, pracowników i konsumentów, a w znacjonalizowanych bankach i towarzystwach ubezpieczeniowych - rady nadzorcze z delegatami branżowych związków zawodowych zamiast przedstawicielstwa konsumentów. Kłopoty z rentownością, z jakimi szybko zaczął zmagać się niemal cały francuski sektor państwowy, sprawiły, że od 1948 r. pojawiało się ze strony administracji centralnej coraz więcej elementów kontroli ex ante, dotyczącej zwłaszcza aspektów finansowych ${ }^{127}$.

\section{Nacjonalizacja w Wielkiej Brytanii (1946-1949)}

Brytyjskie prawodawstwo nacjonalizacyjne odznaczało się największym legalizmem. Po drugiej stronie kanału La Manche nie występowały bowiem ani problemy francuskie (kilkuletni stan prowizorium ustrojowego), ani austriackie (brak statusu państwowego, podział na strefy okupacyjne). Nacjonalizacja dokonywana była zawsze na mocy ustawowej zgodnie z wymogami prawa konstytucyjnego i procedurami legislacji. Uchwalono i wprowadzono w życie jedenaście ustaw, znacznie więcej niż w Austrii i znacznie mniej od sumy odnośnych aktów nacjonalizacyjnych we Francji.

Dwie z brytyjskich ustaw były ukierunkowane „punktowo”, pozostałe odnosiły się do określonych dziedzin przemysłu, infrastruktury bądź usług. Kolejno nacjonalizacja obejmowała: Bank Anglii (luty 1946 r.), górnictwo węgla kamiennego (lipiec 1946 r.; poza najmniejszymi kopalniami), lotnictwo cywilne (sierpień 1946 r.; w tym połączenia zagraniczne, gdyż ustawę z 1939 r. częściowo zahamowała wojna), firmę Cable and Wireless Ltd. (listopad 1946 r.; zewnętrzna łączność radiowa i telegraficzna), transport kolejowy, drogowy i wodny (sierpień 1947 r.; bez lokalnego samochodowego w granicach 25-40 mil), elektroenergetykę (sierpień 1947 r.; z odrębną organizacją dla północnej Szkocji), gazownictwo (lipiec 1948 r.), szpitale i inne ośrodki usług medycznych (Anglia i Walia - listopad 1946r., Szkocja - maj 1947 r.; Irlandia Północna - marzec 1948 r.; bez podmiotów podległych władzom lokalnym) oraz przemysł żelaza i stali (listopad 1949 r.; z wyłączeniem produkcji końcowej i na własne potrzeby) $)^{128}$.

\footnotetext{
127 A. Makać, op.cit., s. 96-97; A. Wieczorkiewicz, op.cit., s. 110-113 i n.

128 Por. N. Chester, The nationalisation of British industry, Her Majesty's Stationary Office, London 1975, s. 38, 100-101, 137-138, 142-143, 182, 193-194, 429, 431-433, 1031; A. Makać, op.cit., s. 45-48 (tabl. 1), 94-95; L. Tivey, op.cit., s. 44-48, 50-52, 56-61; M. Abramovitz, V.F. Eliasberg, The nationalized industries and services, w: The growths of public employment in Great Britain, red. M. Abramovitz, V.F. Eliasberg,
} 
W nawiasach podano daty uzyskiwania sankcji królewskiej. Tzw. vesting day, czyli dzień transferu praw własnościowych $\mathrm{z}$ rąk dotychczasowych właścicieli na rzecz państwa ${ }^{129}$, nastąpił w jednym przypadku tego samego dnia (lotnictwo cywilne), w większości pozostałych ze zwłoką kilku miesięcy ${ }^{130}$. Najdłużej na włączenie do sektora państwowego czekały służba zdrowia (do lipca 1948 r.) oraz przemysł żelaza i stali (do lutego 1951 r.).

Nacjonalizacja szpitali i innych jednostek usług medycznych - łącznie ponad 3 tys. podmiotów - stanowiła część prawodawstwa powołującego powszechną i bezpłatną służbę zdrowia (National Health Service). Pracy w nowym systemie odmawiała jednak większość lekarzy, a jego twórca, minister zdrowia Aneurin Bevan, potrzebował czasu na przełamanie oporu, co osiągnął drobnymi ustępstwami (trochę „płatnych łóżek” w szpitalach, „opłaty konsultacyjne” za niektóre usługi medyczne itp. $)^{131}$. Z kolei nacjonalizacja przemysłu żelaza i stali - bardzo kontrowersyjna ze względu na wysoką rentowność i produkcyjność branży - napotkała poważną obstrukcję ze strony związków pracodawców (British Iron and Steel Federation) oraz Izby Lordów. Ponieważ sprawę procedowano, i to bez specjalnego pośpiechu, jako ostatnią z labourzystowskiego pakietu nacjonalizacyjnego, Izba Gmin przekroczyła termin, po którym ewentualne weto odraczające izby wyższej uniemożliwiało wejście w życie ustawy przed wyborami parlamentarnymi 1950r. W tej sytuacji rząd Partii Pracy wolał sam porozumieć się z przeciwnikami co do przesunięcia nacjonalizacji przemysłu żelaza i stali na 1951 r. W zamian zyskał bardziej koncyliacyjne stanowisko Izby Lordów, wcześniejszą sankcję królewską oraz czas na osłabienie napięcia w stosunkach z BISF ${ }^{132}$.

Każda brytyjska nacjonalizacja wiązała się z ekwiwalentnym odszkodowaniem dla byłych właścicieli ${ }^{133}$. Przejęcia Banku Anglii i Cable and Wireless Ltd., z uwagi

Princeton University Press, Princeton 1957, s. 86-87, 94, 96-97. W dziedzinie elektroenergetyki prawodawstwo z 1947 r. było drugim etapem nacjonalizacji, ponieważ część linii przesyłowych państwo przejęło już w 1926 r. Odrębna organizacja produkcji i dystrybucji energii elektrycznej w północnej Szkocji datowała się od 1943 r. (wówczas całkowicie w gestii władz lokalnych).

${ }^{129}$ W przypadku niektórych nacjonalizacji, zwłaszcza transportu samochodowego oraz przemysłu żelaza i stali, vesting day miał znaczenie tylko nominalne, gdyż faktyczny transfer akcji przebiegał stopniowo.

${ }_{130}$ N. Chester, op.cit., s. 38, 332, 366-370, 406, 1011-1012.

131 Por. C. Webster, The National Health Service. A political history, Oxford University Press, Oxford-New York 1998, s. 29 i n.; H.H. Eckstein, The politics of the British Medical Association, „The Political Quarterly” 1955, Vol. 26, Nr 4, s. 345-359; S. Sheard, A creature of its time: the critical history of the creation of the British NHS, s. 434-436, www.michaelquarterly.np.pdf/2011/4-428-41.pdf [dostęp 8.03.2016].

132 Por. N. Chester, op.cit., s. 35-38, 60-61, 176-177, 181, 370-371; M.E. Tookey, The Labour Party and nationalisation from Attlee to Wilson, 1945-1968: beyond the commanding heights, Durham University, December 2000, s. 72-76, www.etheses.dur.ac.uk./4552/1/4522_1986.pdf [dostęp 8.03.2016].

133 Szczegółową analizę zasad oraz szacunek ogólnej sumy odszkodowań przedstawił N. Chester, op.cit., s. 217-331, 1017-1018. Inne szacunki zob. A. Makać, op.cit., s. 51. 
na "punktowy” charakter, polegały wyłącznie na przymusowym wykupie aktywów, nie pociągając za sobą zmian organizacyjnych. Aktywa Banku Anglii znalazły się w dyspozycji Ministerstwa Skarbu, aktywa Cable and Wireless Ltd. - Urzędu Głównego Poczmistrza (Postmaster General Office) ${ }^{134}$. Wszystkie inne akty nacjonalizacyjne prowadziły do powoływania korporacji publicznych, skupiających pod wspólnym zarządem przedsiębiorstwa o tym samym profilu gałęziowym lub branżowym, uprzednio poddawane jeszcze rozmaitym przymusowym przekształceniom i fuzjom. Podobnie jak w Austrii i Francji powiększało to stopień koncentracji i centralizacji gospodarki. National Coal Board w pierwszym dniu swego istnienia (1 stycznia 1947 r.) skupiała 800 firm górniczych wobec 1470 działających wcześniej ${ }^{135}$. Większość brytyjskich korporacji publicznych, obok zarządu ogólnokrajowego, posiadało jeszcze od kilku do kilkunastu zarządów terytorialnych lub branżowych ${ }^{136}$. Największym molochem była początkowo British Transport Commission, utworzona z początkiem $1948 \mathrm{r}$.; sam tylko pion towarowych przewozów drogowych obejmował 3800 firm, a istniały jeszcze piony transportu kolejowego, pasażerskiego, śródlądowego i dwa inne ${ }^{137}$.

Najważniejszą przesłanką powojennej brytyjskiej nacjonalizacji było spektakularne zwycięstwo labourzystów w wyborach lipcowych 1945 r. Uzyskali oni prawie 48\% ogółu oddanych głosów, a w konsekwencji absolutną większość w Izbie Gmin (393 mandaty w stosunku do 197 zdobytych przez Partię Konserwatywną i 50 przez inne ugrupowania) $)^{138}$. Po raz pierwszy w historii mogli więc sięgnąć po samodzielne i większościowe rządy.

W grę wchodziło jednak jeszcze parę innych ułatwiających okoliczności. Partia Pracy obejmowała władzę z pozycji niedawnego współkoalicjanta konserwatystów w gabinecie wojennym Winstona Churchilla. Koalicję opuściła na dwa miesiące przed wyborami, przywódcy i działacze byli więc dobrze obeznani z aktualiami politycznymi i gospodarczymi, stosunkowo wcześnie zaczęli też liczyć się z perspektywą

134 Oba akty nacjonalizacji w pewnym sensie dopełniały istniejący stan faktyczny. Bank Anglii już od lat 30. znajdował się pod ścisłą kontrolą rządu. Nacjonalizację z 1946 r. kanclerz skarbu, Hugh Dalton, przyrównał do małżeństwa zawartego dla uniknięcia dalszego „życia w grzechu”. Firmę Cable and Wireless Ltd., powstałą w 1929 r. i zabezpieczającą łączność głównie w strefie Commonwealthu, poddano częściowej etatyzacji w 1938 r. (w drodze rynkowego zakupu mniejszościowego pakietu akcji). W 1948 r. prawa własności upaństwowionej Cable and Wireless Ltd. zostały podzielone między poszczególne kraje Commonwealthu. L. Tivey, op.cit., s. 44-45, 50; N. Chester, op.cit., s. 16.

135 W. Ashworth (współpr. M. Pegg), A History of British coal industry, Vol. V, 1946-1982: the nationalized industry, Clarendon Press, Oxford 1986, s. 6-7.

${ }^{136}$ L. Hannah, op.cit., s. 94-95; R. Pryke, Public enterprise in practice: the British experience of nationalisation over two decades, MacGibbon \& Kee, London 1971, s. 26-27.

137 L. Hannah, op.cit., s. 94.

138 General Election of $5^{\text {th }}-19^{\text {th }}$ July 1945 , op.cit. 
wygranych wyborów i podjęli odpowiednie przygotowania ustawowe, w tym w kwestii nacjonalizacji ${ }^{139}$. Przy tym labourzyści nie mieli na nią bynajmniej w Wielkiej Brytanii monopolu. Przed 1945 r. koncepcje, a co ważniejsze praktyki nacjonalizacyjne były udziałem wszystkich głównych sił politycznych. Partia Pracy tradycyjnie chciała wprawdzie nacjonalizacji najdalej idącej ${ }^{140}$, ale w międzywojniu przeprowadzały ją za każdym razem rządy konserwatystów albo przez nich zdominowane ${ }^{141}$. Wcześniej zaś nacjonalizowali liberałowie ${ }^{142}$. Dorobkiem dawniejszych rządów liberalnych i konserwatywnych była też większość etatyzacji. Pozwalało to labourzystom prezentować powojenną nacjonalizację jako kontynuację historycznie ugruntowanej linii polityki gospodarczej. Tym bardziej że rozbudowa własnościowej domeny państwa cieszyła się po 1945 r. o wiele szerszym niż w okresie międzywojennym poparciem opinii publicznej.

Właśnie rozminięcie się z preferencjami przeważającej części obywateli przesądziło o porażce torysów w wyborach 1945 r. Partia Pracy, poza nacjonalizacją części sektora prywatnego, obiecywała w kampanii wyborczej rozbudowę systemów ubezpieczeń i zasiłków, emerytur i rent, edukacji i ochrony zdrowia, pośrednictwa pracy i budownictwa mieszkaniowego ${ }^{143}$. Program ten, ewidentnie wyrastający $\mathrm{z}$ ducha raportu Williama Beveridge’a z 1942 r. ${ }^{144}$, przedstawiała jako gwarancję mniejszych zróżnicowań dochodowych i majątkowych, awansu materialnego warstw niższych oraz ogólnospołecznego bezpieczeństwa socjalnego. W tym czasie przywódca konserwatystów, premier W. Churchill, przejęty stanem państwowych finansów nawoływał, by „pozostawić socjalistycznych marzycieli ich własnej utopii”. Zaprzeczało

139 P. Addison, The road to 1945: British politics and the Second World War, rev. ed., Pimlico, London 1994, s. 54 i n.; N. Chester, op.cit., s. 5-6, 22-23, 43-44.

140 R. Eldon Barry, Nationalisation in British politics: the historical background, Stanford University Press, Stanford, Calif. 1965, passim.

${ }^{141}$ Dotyczyło to nacjonalizacji radiofonii i części przesyłu elektryczności (1926 r.; rząd Stanleya Baldwina), transportu londyńskiego i złóż ropy naftowej (lata 1933-1934; rząd Ramseya MacDonalda) oraz złóż węgla kamiennego i cywilnych przewozów lotniczych (lata 1938-1939; rząd Neville’a Chamberlaina).

${ }^{142}$ Chodzi o nacjonalizację linii telegraficznych (1869 r.; rząd Williama E. Gladstone’a) i telefonicznych (1912 r.; rząd Herberta H. Asquitha).

${ }^{143}$ Let us face the future: A declaration of Labour policy for the nation, Fabian Society, London 1945, s. 4-10; J. Singleton, op.cit., s. 17-19, 21-22. Istnieje też pogląd, że porażka wyborcza Partii Konserwatywnej w $1945 \mathrm{r}$. to odłożony w czasie skutek jej polityki z lat 1939-1940, kiedy to miała trwale utracić dużą część elektoratu. R. McKibbin, Parties and people: England 1914-1951, Oxford University Press, Oxford 2010, s. 119 i n.

144 W. Beveridge w latach 1919-1937 kierował London School of Economics. Pierwotnie związany z Towarzystwem Fabiańskim, ostatecznie w 1944 r. przystąpił do Partii Liberalnej. Raport z 1942 r. - Social Insurance and Allied Services - opracował na zamówienie wojennego gabinetu W. Churchilla. Tak jak koncepty nacjonalizacyjne, podobnie wizje nowej polityki społecznej Partii Pracy miały wiele do zawdzięczenia liberałom i konserwatystom. Interesujące uwagi na ten temat poczynił np. K.O. Morgan, Labour in power, 1945-1951, Clarendon Press, Oxford 1984, s. 142-143. 
to polityce z ostatnich dwóch lat wojny, kiedy kierowany przezeń rząd rozpoczął prace nad urzeczywistnieniem propozycji W. Beveridge'a ${ }^{145}$.

Na czele większościowego rządu Partii Pracy stanął jej lider, Clement Attlee, wicepremier w wojennej koalicji z Partią Konserwatywną. Odpowiedzialnym za realizację programu nacjonalizacji był wicepremier Herbert Morrison, wieloletni przywódca labourzystów londyńskich. Miał on stosowne doświadczenie praktyczne z lat 1929-1931, gdy jako minister transportu przygotowywał upaństwowienie stołecznych przewozów pasażerskich ${ }^{146}$. Odegrał również decydującą rolę w przekonaniu partii i jej zaplecza związkowego do powiązania postulatów nacjonalizacji z koncepcją korporacji publicznych, pełnym odszkodowaniem dla byłych właścicieli oraz rezygnacją z idei zarządzania przez robotników przedsiębiorstwami (a nawet udziału w zyskach) ${ }^{147}$. Przy całej swej lewicowości H. Morrison był politykiem przede wszystkim pragmatycznym. Ostrożny wobec wielkich wizji ideowych, zagadnienie nacjonalizacji rozpatrywał niemal wyłącznie w kategoriach użyteczności ekonomicznej, społecznej i politycznej ${ }^{148}$.

145 Cytat z W. Churchilla za: W. Laqueur, op.cit., s. 53. Między lutym 1944 r. a majem 1945 r. rząd W. Churchilla firmował serię tzw. white papers, poświęconych kolejno ochronie zdrowia, pełnemu zatrudnieniu, ubezpieczeniom społecznym i budownictwu mieszkaniowemu. W drodze zaś ustaw parlamentarnych poszerzono i wydłużono obowiązkowe nauczanie oraz ustanowiono zasiłki dla rodzin $\mathrm{z}$ dwojgiem i większą liczbą dzieci. P. Howlett, The war-time economy, 1939-1945, w: The Cambridge..., op.cit., s. 23; W. Prescott, British conservatism, 1945-1951: adapting to the age of collectivism, The University of Adelaide, March 2015, s. 33-35, 67-70, 94-96, https://digital.library.adelaide.edu.au/dspace/bitstream/2440/95244/3/0.pdf [dostęp 7.03.2016].

146 Funkcję ministra transportu H. Morrison piastował w mniejszościowym rządzie Partii Pracy, kierowanym przez R.Mac. Donalda i wspieranym w parlamencie przez Partię Liberalną. Ustawę nacjonalizującą transport londyński uchwalono w 1933 r., gdy Partia Pracy znajdowała się już w opozycji. Premierem był nadal R. MacDonald, który najpierw w sierpniu 1931 r. podał się do dymisji, a następnie wraz z kilkoma innymi labourzystami zawarł koalicję z konserwatystami i liberałami. Został za to usunięty z partii, a swoich zwolenników skupił w niewielkiej Narodowej Partii Pracy.

147 Y. Tōyama, The origins of nationalization in Britain (III), „Otemon Economic Studies” 1975, Vol. 8, s. 7-18; M.E. Tookey, op.cit., s. 42-44. Zob. też H. Morrison, Socialisation and transport: the organisation of socialist industries with particular reference to the London Passenger Transport Bill, Constable \& Co, Ltd., London 1933, s. 39, 137, 139, 149, 165-171, 174, 178-179, 209-212, 244-245. Formułę korporacji publicznej, wypracowaną przez konserwatystów i popieraną przez liberałów, Partia Pracy zaadaptowała na początku lat 30. XX w. Przedtem opowiadała się za włączaniem upaństwawianych podmiotów wprost do administracji rządowej (na podobieństwo usług pocztowych, telegraficznych i telefonicznych). Udział robotników w zarządzaniu i zyskach przedsiębiorstw promowali wcześniej zwłaszcza teoretycy socjalizmu gildyjnego.

${ }^{148}$ W 1945 r. H. Morrison został nie tylko wicepremierem, ale także liderem Izby Gmin, Lordem Przewodniczącym Rady oraz szefem dwóch specjalnych komitetów koordynujących zasady i przebieg nacjonalizacji. W 1951 r. był krótko następcą Ernesta Bevina na stanowisku ministra spraw zagranicznych. Poza H. Morrisonem, pilotującym większość ustaw nacjonalizacyjnych, duży wpływ na ich treść mieli też niektórzy szefowie resortów, przede wszystkim wspominani już A. Bevan (zdrowie) i H. Dalton (skarb) oraz Alfred Barnes (transport), Emanuel Shinwell (energetyka), Hugh Gaitskell (następca Shinwella; później skarb) oraz George Strauss (zaopatrzenie). Zob. K.O. Morgan, op.cit., passim. 
W parlamencie Wielkiej Brytanii, inaczej niż w Austrii i Francji, istniała poważna antynacjonalizacyjna opozycja. Była nią Partia Konserwatywna, która jednak przeciwstawiała się odnośnym ustawom dość miękko. W Izbie Gmin występowała i głosowała wprawdzie zawsze przeciwko, ale w Izbie Lordów, gdzie tradycyjnie posiadała większość, poprzestawała na formułowaniu poprawek zamiast po prostu odrzucać prawodawstwo nacjonalizacyjne. Wynikało to nie tylko z siły wyborczego mandatu Partii Pracy i stosunkowo słabej pozycji izby wyższej (wyłącznie weto odraczające), ale także z podzielania przez część konserwatystów potrzeby niektórych nacjonalizacji. Nawet stosując obstrukcję w Izbie Gmin, torysi zastrzegali zwykle, że kontestują nie samą zasadę nacjonalizacji, ale treść konkretnych ustaw. Na największy opór zdecydowali się przy ustawie dotyczącej przemysłu żelaza i stali, ale i ona - po przesunięciu realizacji na 1951 r. - ostatecznie przeszła przez Izbę Lordów ${ }^{149}$. Partia Liberalna, ugrupowanie W. Beveridge’a i Johna M. Keynesa, reagowała jeszcze łagodniej. Oprotestowała tylko nacjonalizację transportu wewnętrznego oraz przemysłu żelaza i stali. W pozostałych przypadkach głosowała w obu izbach parlamentu „za”"150.

Partiom opozycyjnym kontrakcji nie ułatwiały zręczne uzasadnienia kolejnych ustaw nacjonalizacyjnych. Labourzyści reklamowali je jako panaceum na kłopoty z rentownością i rozdrobnieniem organizacyjnym, brak perspektyw inwestycyjnych i modernizacyjnych, załamanie eksportu i niedobory finansowe, redukcje zatrudnienia i płac, dysproporcje majątkowe i dochodowe, niesprawiedliwe stosunki pracy itd. Dość często szermowano też względami strategicznymi (w duchu koncepcji commanding heights i planowania gospodarczego). Zarazem, choć w Partii Pracy działało głośne lewe skrzydło, długo udawało się marginalizować bądź maskować motywacje ideologiczne $e^{151}$.

149 G. Hodgson, The steel debates: the Tory recovery, w: Age of austerity, 1945-1951, red. M. Sissons, P. French, Oxford University Press, Oxford 1986, s. 297-316. Wielu autorów pisze o swoistym konsensusie między konserwatystami a labourzystami co do częściowej nacjonalizacji i budowania welfare state. Podłożem miała być koalicyjna współpraca z czasów wojny, a konsekwencją zachowanie przez Partię Konserwatywną po powrocie do władzy większości reform własnościowych i społecznych z lat 1945-1951. Zob. np. D. Kavanagh, The postwar consensus, „Twentieth Century British History” 1992, Vol. 3, Nr 2, s. 175-190; P. Addison, op.cit., s. 273-275. Nowsze analizy dowodzą, że polityka konserwatystów była wyrazem nie tyle bliskości koncepcyjnej z labourzystami, ile obranej taktyki. W. Prescott, op.cit., s. 7, 43-54, 63-64, 75-78; M.E. Tookey, op.cit., s. 67.

150 P. Sloman, The Liberal Party and the economy, Oxford University Press, Oxford 2015, s. 166 i n.

151 Szerzej o uzasadnieniach towarzyszących labourzystowskim nacjonalizacjom por. M. Abramovitz, V.F. Eliasberg, op.cit., s. 88-90, 92-97; M. Francis, Ideas and politics under Labour, 1945-1951: building a new Britain, Manchester University Press, Manchester 1997, s. 65-99; R. Millward, The 1940 s nationalization in Britain. Means to an end or the means of production, „The Economic History Review” 1997, Vol. 50, Nr 2, s. 209-234; R. Toye, The Labour Party and the planned economy, 1931-1951, Boydell Press, Rochester, N.Y. 2003, s. 185-235. 
Po roku 1946 labourzyści coraz częściej różnili się wewnętrznie. H. Morrison i inni umiarkowani dystansowali się od rozciągania nacjonalizacji na transport drogowy, a zwłaszcza przemysł żelaza i stali. Sceptycyzm wyrażały nawet labourzystowskie związki zawodowe, $\mathrm{z}$ kolei pronacjonalizacyjna frakcja w rządzie i partii zaczęła sięgać po argumenty ideologiczne. Głównym zwolennikiem wypełnienia wszystkich zapowiedzianych upaństwowień, a następnie wystąpienia z kolejnymi, był A. Bevan ${ }^{152}$. Wątpliwości w Partii Pracy jednak pogłębiały się, szczególnie po dostrzeżeniu, że dokonana już nacjonalizacja nie redystrybuuje w dół drabiny społecznej ani bogactwa, ani władzy ekonomicznej, za to generuje większe od spodziewanych koszty i deficyty ${ }^{153}$. Inną przyczyną były narastające trudności ekonomiczne i polityczne, zarówno wewnętrzne, jak i zewnętrzne ${ }^{154}$.

W lutym 1950 r. odbyły się wybory parlamentarne. Partia Pracy wygrała, zdobywając 46\% głosów, ale jej przewaga w Izbie Gmin zmalała do 17 posłów nad Partią Konserwatywną i pięciu nad całą opozycją ${ }^{155}$. W marcu 1950 r. wybuchła wojna w Korei, bardzo silnie podkręcając zbrojenia. Wkrótce zaczęły kumulować się koszty systemu ochrony zdrowia i całej polityki społecznej ${ }^{156}$. Zmusiło to rząd C. Attlee do oszczędności, firmowanych przez nowego kanclerza skarbu Hugh Gaitskella. W kwietniu 1951 r. na znak protestu do dymisji podali się A. Bevan i dwaj inni członkowie gabinetu $^{157}$. W tych warunkach chwiejący się rząd zdecydował się rozpisać jesienią przedterminowe wybory.

152 Por. J. Singleton, op.cit., s. 23, 27; R. Ranieri, Partners and enemies: the government's decision to nationalise steel 1944-1948, w: The political..., op.cit., s. 275, 289-290; M.E. Tookey, op.cit., s. 68-71, 73-76, 84. Do stronników H. Morrisona należeli m.in. E. Shinwell (w październiku 1947 r. zamienił resort energetyki na resort obrony) i William Jowitt (Lord Kanclerz). Stronę A. Bevana trzymali zwykle H. Dalton (do listopada 1947 r. kanclerz skarbu, od lutego 1950 r. minister planowania przestrzennego), Stafford Cripps (do listopada 1950 r. następca H. Daltona w resorcie skarbu) oraz sam premier C. Attlee.

153 J. Tomlinson, Democratic socialism and economic policy: the Attlee years, 1945-1951, Cambridge University Press, Cambridge 1997, s. 101-102, 117-120; M.E. Tookey, op.cit., s. 76-83, 85-87; A. Makać, op.cit., s. 66 i n.

154 Szerzej na ten temat M. Chick, Industrial policy in Britain, 1945-1951. Economic planning, nationalisation and Labour goverments, Cambridge University Press, Cambridge 1998, s. 103 i n.

155 General Election of $23^{\text {rd }}$ February 1950, op.cit. Przed wyborami labourzyści doprowadzili do zmniejszenia liczby miejsc w Izbie Gmin z 640 do 625. Usunięto tzw. wirylistów, w większości o nastawieniu konserwatywnym.

${ }^{156}$ Poza ustanowieniem National Health Service rząd Partii Pracy upowszechnił i podniósł m.in. ubezpieczenia emerytalne i zdrowotne oraz zasiłki rodzinne i chorobowe. Rozwijał też program taniego budownictwa mieszkaniowego (głównie jednorodzinnego) i zainaugurował negocjacyjny mechanizm ustalania płac robotniczych. Zob. np. M. Kovar, The origins of the British welfare state and its functions in 1945-1951, www.usd.ff.cuni.czech/?q=/system/files/kovar_1.pdf [dostęp 10.03.2016]; R. Lowe, The welfare state in Britain since 1945, MacMillan, London 1993, s. 65 i n.

157 W tym czasie A. Bevan szefował resortowi pracy i służby narodowej (od stycznia 1951 r.). Jednym z ministrów, którzy dołączyli się do dymisji A. Bevana, był Harold Wilson, późniejszy trzykrotny premier. 
Od lutego 1951 r. trwała zaległa nacjonalizacja przemysłu żelaza i stali. Nie otwierano natomiast nowych frontów nacjonalizacyjnych. Deklaracja wyborcza z 1950 r. wymieniała ich całkiem sporo: od przetwórstwa buraków cukrowych i rafinacji cukru, przez przemysł cementowy, część chemicznego, chłodnictwo, hurtowy handel mięsem, dostawy wody i niektóre minerały, po wielkie koncerny o monopolistycznej pozycji na rynku. Entuzjazm do poszerzania sektora państwowego wyparowywał jednak bardzo szybko. W manifeście wyborczym z 1951 r. Partia Pracy wspominała już tylko o możliwości nacjonalizacji koncernów ${ }^{158}$.

Obawy labourzystów co do wyniku wyborów spełniły się. W październiku 1951 r. padło na nich o $0,8 \%$ więcej głosów niż na konserwatystów (48,8\% do 48,0\%), ale w Izbie Gmin większość zdobyli ci drudzy (przewaga 26 i 17 mandatów - odpowiednio - nad Partią Pracy i całą opozycją) ${ }^{159}$. Powrót do władzy Partii Konserwatywnej z jednej strony przekreślił wszelkie dalsze plany nacjonalizacyjne, a z drugiej strony otworzył możliwość zawężenia sektora państwowego. W 1953 r. nowy rząd doprowadził do rozpoczęcia prywatyzacji przemysłu żelaza i stali oraz dalekobieżnego transportu drogowego. Nie podważono natomiast innych labourzystowskich nacjonalizacji, ani w przemyśle, ani w infrastrukturze, ani w usługach medycznych ${ }^{160}$.

\section{Wnioski porównawcze}

We wszystkich analizowanych państwach nacjonalizacja - różna pod względem zasięgu, liczby implementujących aktów prawnych, formuły odszkodowań itd. - była „dzieckiem” swego czasu politycznego. Każdorazowo przeprowadzano ją w warunkach rządów partii o programach jednoznacznie pronacjonalizacyjnych. W Austrii i Francji były to rządy koalicyjne (w pierwszym przypadku chadeków i socjalistów, w drugim chadeków, socjalistów i komunistów), zaś w Wielkiej Brytanii jednopartyjne (labourzystów). Równie sprzyjające okoliczności polityczne nie wystąpiły w żadnym innym państwie zachodnioeuropejskim. Wyjaśnia to, dlaczego na tym obszarze geopolitycznym powojenna nacjonalizacja dokonana została wyłącznie w Austrii, Francji i wielkiej Brytanii.

158 L. Tivey, op.cit., s. 206-207; J. Singleton, op.cit., s. 16 (Tab. 2.1).

159 General Election of 25 $5^{\text {th }}$ October 1951, op.cit. Partia Konserwatywna wzięła większość głównie ze względu na straty poniesione przez Partię Liberalną.

160 Więcej na ten temat zob. W. Prescott, op.cit., s. 2, 56-64. 
Wewnętrzne układy polityczne - z wyjątkiem Austrii - decydowały też o porzucaniu polityki nacjonalizacji. We Francji przesądziło o tym wypadnięcie komunistów z koalicji rządowej, w Wielkiej Brytanii wewnętrzne przesunięcia w Partii Pracy, a ostatecznie jej porażka w wyborach parlamentarnych. Natomiast w Austrii w latach 1946 i 1947 znacjonalizowano na tyle dużo, że wobec determinacji do zachowania systemu kapitalistycznego rządzący wspólnie jeszcze przez wiele lat chadecy i socjaliści rozbudowywali sektor państwowy już tylko metodą etatyzacji (jeśli nie liczyć skonsumowania po 1955 r. nacjonalizacji w dawnej strefie ZSRR).

Niezależnie od biegu spraw we Francji współwładza partii komunistycznej nie była warunkiem koniecznym zachodnioeuropejskich nacjonalizacji. W Austrii doszłoby do nich również bez udziału komunistów w rządzie (zresztą bardzo symbolicznego), w Wielkiej Brytanii tak właśnie się stało. Powojenna kapitalistyczna nacjonalizacja w znacznie większym stopniu zależała od pozycji zajmowanej przez demokratycznych i reformistycznych socjalistów (socjaldemokratów). To dlatego ominęła ona m.in. RFN i Włochy, których sceny polityczne początkowo samodzielnie zdołały zagospodarować partie chrześcijańsko-demokratyczne. Jednakże współrządy, ani nawet rządy socjalistów czy socjaldemokratów same w sobie nie wystarczały. W Skandynawii, gdzie było to standardem, po nacjonalizację nie sięgano.

Warunki formalne, w jakich przebiegała zachodnioeuropejska nacjonalizacja, były skrajnie odmienne. Od całkowicie legalistycznych w Wielkiej Brytanii, przez początkowe prowizoria ustrojowe we Francji, po brak statusu państwowego i zewnętrzną okupację w Austrii. Prawodawstwo nacjonalizacyjne najłatwiej przychodziło wprowadzać w życie we Francji, gdzie - mimo ostrych sporów o jego zakres - brakowało liczących się sił antynacjonalizacyjnych. W Wielkiej Brytanii napotykano trudności ze strony opozycyjnej Partii Konserwatywnej (zwłaszcza casus przemysłu żelaza i stali) oraz niektórych przedstawicielstw zawodowych (zwłaszcza casus szpitali). W Austrii, gdzie podobnie jak we Francji nie było poważniejszej obstrukcji w parlamencie, praktykę nacjonalizacyjną skutecznie opóźniły okupacyjne władze radzieckie.

O zasięgu nacjonalizacji brytyjskiej i francuskiej decydowały głównie kalkulacje ekonomiczne. Z kolei w Austrii decydujące okazały się motywacje polityczne (w zasadzie bez konotacji ideologicznych), związane z ochroną rodzimej gospodarki przed zakusami mocarstw okupacyjnych, w pierwszym rzędzie ZSRR. Rzecz jasna, w każdym z tych przypadków idzie o generalne proporcje czynników determinujących kształt nacjonalizacji. Żaden z nich nie zyskał nigdy wyłączności, a obok ekonomicznych i politycznych występowały, choć w skromniejszym wymiarze, także społeczne i polityczno-ideologiczne. 
Drugoplanowe znaczenie tych ostatnich w warunkach nacjonalizacji kapitalistycznej raczej nie budzi zdziwienia. Należało się natomiast spodziewać przykładania większej uwagi do demokratyzacji stosunków pracy (demokracji robotniczej). Tymczasem w Wielkiej Brytanii programowo z niej zrezygnowano (wraz z przyjęciem koncepcji korporacji publicznej), zaś w Austrii i Francji realizacja nie wyszła poza stadia cząstkowe. Na paradoks zakrawa fakt, że w znacznie większym stopniu dbano o koncentracyjno-konsolidacyjne efekty nacjonalizacji.

\section{Bibliografia}

Abramovitz M., Eliasberg V.F., The nationalized industries and services, w: The growths of public employment in Great Britain, red. M. Abramovitz, V.F. Eliasberg, Princeton University Press, Princeton 1957.

Addison P., The road to 1945: British politics and the Second World War, rev. ed., Pimlico, London 1994.

Andrieu C., La banque sous l'occupation. Paradoxes de l'histoire d'une proffesion, Presses de la Fondation Nationale des Sciences Politiques, Paris 1990.

Ashworth W. (współpr. M. Pegg), A History of British coal industry, Vol. V, 1946-1982: the nationalized industry, Clarendon Press, Oxford 1986.

Austria. Economic growth and government policy, www.countrystudies.us/Austria/84.htm

Baarbar [B.-E. Batbajar], Dzieje Mongolii, tłum. S. Grodziński, Dialog, Warszawa 2005.

Bader W.B., Austria between East and West 1945-1955, Stanford University Press, Stanford, Cal. 1966.

Barjot D., To rebuild France after WW2: the beginnings of électricité de France (1946-1953), EBHA conference, 24-26 August 2011, Athens, www.ebha.org/ebha2011/files/Papers/ Athens.pdf

Barker E., Austria 1918-1972, University of Miami Press, Miami, Flo. 1973.

Baszkiewicz J., Historia Francji, Zakład Narodowy im. Ossolińskich, Wrocław-Warszawa-Kraków-Gdańsk 1974.

Baykov A., The development of the Soviet economic system, Cambridge University Press, Cambridge-New York 1947.

Becker W., The emergence and development of christian democratic parties in Western Europe, w: Christian democracy in the European Union [1945/1995]. Proceedings of the Leuven Colloquium 15-18 November 1995, Leuven University Press, Leuven 1997.

Béthouart B., Entry for Catholics into the Republic: the Mouvemen Républucain Populaire in France, w: Christian democracy in Europe since 1945, Vol. 2, red. M. Gehler, W. Keiser, Routledge, London-New York 2004. 
Binder D.A., "Resciuing the Christian Occident” and „Europe in us”: The People's Party in Austria, w: Christian democracy in Europe since 1945, Vol. 2, red. M. Gehler, W. Keiser, Routledge, London-New York 2004.

Bischof G., Allied plans and policies for the occupation of Austria 1938-1955, w: Austria in the twentieth century, red. R. Steininger, G. Bischof, M. Gehler, Transaction Publishers, New Brunswick, N.J.-London 2002.

Brus W., Histoire économique de l'Europe de l'est, Le Découverte, Paris 1986.

Brzeziński B., Kalendarium ważniejszych wydarzeń dotyczących nacjonalizacji przemysłu $w$ socjalistycznych krajach Europy, w: Nacjonalizacja w świecie współczesnym, Książka i Wiedza, Warszawa 1978.

Buchanan J., Post-socialist political economy. Selected essays, Edward Elgar Publishing, Cheltenham-Lyme, N.H. 1997.

Bucheli M., Decker S., Economic nationalism in Latin America and Africa in the twentieth century: a Comparison, [2014], www.worldbhc.org/files/fullprogram/A2_B2_DekerBucheli2014Econom.pdf

Butler W.E., The Mongolian legal system. Contemporary legislation and documentation, Martinus Nijhoff Publishers, The Hague 1982.

Chadeau F., The rise and decline of stated-owned industry in twentieth-century France, w: The rise and fall of state-owned enterprise in the western world, red. P. Toninelli, Cambridge University Press, Cambridge 2000.

Chester N., The nationalisation of British industry, Her Majesty's Stationary Office, London 1975.

Chick M., Industrial policy in Britain, 1945-1951. Economic planning, nationalisation and Labour goverments, Cambridge University Press, Cambridge 1998.

Coetzee C., The proposed nationalization of mines in South Africa: a critical assessment, Province of KwaZulu-Natal, Provincial Treasury, IGR Unit, [2010], www.kztnopbusiness.co.za/site/user_data/files/Mine_Nationalization_2pdf

Di Porto F., Energy law in Italy, Wolters Kluwer Law \& Business, b.m.w. 2011.

Dudek W., Nacjonalizacja jako przedmiot stosunków Polski z niektórymi państwami kapitalistycznymi, w: Nacjonalizacja w świecie współczesnym, Książka i Wiedza, Warszawa 1978.

Dumontier P., Lavrin C., The financial impact of the French government nationalization/privatization strategy, October $4^{\text {th }} 2001$, www.affi.asso.fr/uploads/Externe/0d/CTR FICHIER_26_1226069122.pdf

Dunn J., Secularizing the sacred: the effort to dechristianize France during the French Revolution, „Primary Source” 2012, Vol. 4, Nr 1.

Duroselle J.B., Początki katolicyzmu społecznego we Francji 1822-1870, tłum. Z. Jakimiak, Instytut Wydawniczy Pax, Warszawa 1961.

Eckstein H.H., The politics of the British Medical Association, „The Political Quarterly” 1955, Vol. 26, Nr 4. 
Edgerton D., Public ownership and the British arms industry, w: The political economy of nationalisation in Britain, 1920-1950, red. R. Millward, J. Singleton, Cambridge University Press, Cambridge 1995.

Edwards M.A., Nationalization, de-nationalization, re-nationalization. Some historical and comparative perspective, „Pace Law Review” 2009, Vol. 30, Nr 1.

Einaudi M., Nationalisation of industry in Western Europe. Recent literature and debates, „The American Political Science Review” 1950, Vol. 44, Nr 1.

Einaudi M., Bye M., Rossi E., Nationalization: French and Italian experiences, Cornell University Press, Ithaca, N.Y. 1955.

Eldon Barry R., Nationalisation in British politics: the historical background, Stanford University Press, Stanford, Cal. 1965.

Falk W., Ogólne prawidłowości i specyficzne cechy socjalistycznej nacjonalizacji przemysłu w Niemieckiej Republice Demokratycznej, w: Nacjonalizacja w świecie współczesnym, Książka i Wiedza, Warszawa 1978.

Fiedor K., Austria. Od gospodarki żarowej do Unii Europejskiej, Państwowy Instytut Naukowy - Instytut Śląski w Opolu, Opole 2000.

Francis M., Ideas and politics under Labour, 1945-1951: building a new Britain, Manchester University Press, Manchester 1997.

General Election of $5^{\text {th }}-19^{\text {th }}$ July 1945, w: General Election Results $1885-1979$, www.election.demon.co.uk./geresults.html

General Election of 23 ${ }^{\text {rd }}$ February 1950, General Election Results 1885-1979, www.election.demon.co.uk./geresults.html

General Election of 25 ${ }^{\text {th }}$ October 1951, w: General Election Results 1885-1979, www.election.demon.co.uk./geresults.html.

Godelier F., Usinor and the French steel industry: from "private” monopoly to "public" competitor, 1948-2001, „Business and Economic History” 2006, Vol. 4, [on-line], http:// www.thebhc.org./BEH/06/godelier.pdf

Gołębiowski, J., Sektor państwowy w gospodarce Polski międzywojennej, PWN, Warszawa-Kraków 1985.

Gourvish T.R., The business alcohol in the USA and the UK: UK regulation and drinking habits, 1914-1939, „Business and Economic History” 1997, Vol. 26, Nr 2.

Grabska W., Kapitał zachodnioniemiecki w gospodarce Austrii, w: W. Grabska, P. Landau, J. Zdanowicz, Szkice o gospodarce zachodnioeuropejskiej, PISM, Warszawa 1968.

Hafsi T., Privatization and nationalization, w: Encyclopedic dictionary of public administration, red. L. Côté, J.F. Savard, [on-line], www.dictionnaire.enap.ca.pdf

Hannah L., A failed experiment: the state ownership of industry, w: The Cambridge economic history of modern Britain, Vol. III, Structural change and growth, 1939-2000, red. F. Floud, P. Johnson, Cambridge University Press, Cambridge 2004. 
Haynes M., Husan R., Market failure, state failure, institutions, and historical constraints in the East European transition, „Journal of European Area Studies” 2002, Vol. 10, Nr 1.

Hemmerijckx R., The Belgian Communist Party and the socialist trade unions, 1940-60, „Journal of Communist Studies and Transition Politics” 1990, Vol. 6, Nr 4.

Hodgson G., The steel debates: the Tory recovery, w: Age of austerity, 1945-1951, red. M. Sissons, P. French, Oxford University Press, Oxford 1986.

Holton R., Industrial politics in France: nationalisation under Mitterrand, „West European Politics" 1986, Vol. 9, Nr 1.

Holzer J., Europa zimnej wojny, Społeczny Instytut Wydawniczy Znak, Kraków 2012.

Horváth D., Austria - balance at the time of cold war, www.coldwar.hu/html/en/conferences/Other_conferences/Dora_Horvath.pdf

Howlett P., "The thin end of the wedge?": nationalisation and industrial structure during the Second World War, w: The political economy of nationalisation in Britain, 1920-1950, red. R. Millward, J. Singleton, Cambridge University Press, Cambridge 1995.

Howlett P., The war-time economy, 1939-1945, w: The Cambridge economic history of modern Britain, Vol. III, Structural change and growth, 1939-2000, red. F. Floud, P. Johnson, Cambridge University Press, Cambridge 2004.

Imashiro M., Nationalisation of railways and dispute over reconstruction to standard gauge, „Japan Railway \& Transport Review”, March 1995, www.jrtr.net/jrtr.04/pdf/history/pdf

Kaliński J., Bitwa o handel 1947-1948, Książka i Wiedza, Warszawa 1971.

Katzarov K., The theory of nationalisation, Martinus Nijhoff Publishers, The Hague 1964.

Kavanagh D., The postwar consensus, „Twentieth Century British History” 1992, Vol. 3, Nr 2.

Kindleberger Ch.P., French planning, National Bureau of Economic Research www.nber. org/chapters/c1426.pdf

Kleer J., Jugosławiańska reforma gospodarcza, Książka i Wiedza, Warszawa 1970.

Kleer J., Nacjonalizacja $w$ Trzecim Świecie, w: Nacjonalizacja $w$ świecie współczesnym, Książka i Wiedza, Warszawa 1978.

Kline P., Moretii E., Local economic development, agglomeration economies and The Big Push: 100 years of evidence from The Tennessee Valley Authority, November 2013, www. eml.berkeley.edu// moretti/tva.pdf

Kochanowski J., Wegry. Od ugody do ugody. 1867-1990, Trio, Warszawa 1997.

Kołakowski L., Główne nurty marksizmu. Powstanie - rozwój - rozkład, wyd. 2 popr., Wydawnictwo Aneks, Londyn 1988.

Kołomejczyk N., Rewolucje ludowe w Europie 1939-1948, Wiedza Powszechna, Warszawa 1973.

Kovar M., The origins of the British welfare state and its functions in 1945-1951, www.usd. ff.cuni.czech/?q=/system/files/kovar_1.pdf 
Krasuski J., Europa Zachodnia. Dzieje polityczne 1945-1993, Wydawnictwa Szkolne i Pedagogiczne, Warszawa 1995.

Krugman P., What to do, „The New York Review of Books”, 18.12.2008.

Landau Z., Czy w Polsce Ludowej dokonano nacjonalizacji banków, „Przegląd Historyczny” 1969, T. 60, Nr 4.

Langer E., Nationalisations in Austria, „Annals of Public and Cooperative Economics” 1964, Vol. 35, Nr 2-3.

Lappeküper U., Between concentration movement and people's party: The Christian Democratic Union in Germany, w: Christian democracy in Europe since 1945, Vol. 2, red. M. Gehler, W. Keiser, Routledge, London-New York 2004.

Laqueur W., Historia Europy 1945-1992, tłum. R. Zawadzki, Puls, Londyn 1993.

Les nationalisations de la libération. De l'utopie au compromis, red. C. Andrieu, L. Le Van, A. Prost, Presses de la Fondation Nationale des Sciences Politiques, Paris 1987.

Leszczyński A., Skok w nowoczesność. Polityka wzrostu w krajach peryferyjnych 1943-1980, Wydawnictwo Krytyki Politycznej, Warszawa 2013.

Let us face the future: A declaration of Labour policy for the nation, Fabian Society, London 1945.

Lienert I., Where does the public sector end and the private sector begin?, „IMP Working Paper, Fiscal Affairs Department", June 2009, www.inf.org./external/pubs/ft/wp/ 2009wp09122.pdf

Lowe R., The welfare state in Britain since 1945, MacMillan, London 1993.

Luszniewicz J., Gospodarka radziecka w latach 1917-1841, w: Powszechna historia gospodarcza 1918-1931, red. W. [Wojciech] Morawski, Floks, Warszawa 1994.

Luszniewicz J., Nacjonalizacja, w: Nowa encyklopedia powszechna PWN, t. 4, Wydawnictwo Naukowe PWN, Warszawa 1996.

Luszniewicz J., W kreggu gospodarki centralnie kierowanej, w: Powszechna historia gospodarcza 1918-1931, red. W. [Wojciech] Morawski, Floks, Warszawa 1994.

Łaszek A., Samoń D., Tatała M., Opinia Forum Obywatelskiego Rozwoju nt. Projektu Ustawy o zmianie niektórych ustaw w zwiazku z określeniem zasad wypłaty emerytur ze środków zgromadzonych $w$ otwartych funduszach emerytalnych $z$ dnia 10 października $2013 \mathrm{r}$., [Warszawa], 28 października 2013, www.FOR.pdf

Machelon J.P., L'idée de nationalisation en France de 1840 à 1914, w: Administration et contrôle de l'économie: 1800-1914, [M. Bruguiere et al.], Librairie Droz, Genève 1985.

Maier Ch.S., The two postwar eras and the conditions for stability in twentieth-century Western Europe, „The American Historical Review” 1981, Vol. 86, Nr 2.

Makać A., Sektor państwowy w ekonomice rozwiniętych krajów kapitalistycznych, PWN, Warszawa 1971. 
Masala C., Born for government: The Democrazia Christiana in Italy, w: Christian democracy in Europe since 1945, Vol. 2, red. M. Gehler, W. Keiser, Routledge, London-New York 2004.

McKibbin R., Parties and people: England 1914-1951, Oxford University Press, Oxford 2010.

Méchoulan É., Jules Moch un socialiste d'érangeant, Emile Bruylant, Bruxelles-Paris 2000.

Michałek K., Na drodze ku potędze. Historia Stanów Zjednoczonych Ameryki 1861-1945, Książka i Wiedza, Warszawa 1991.

Miliband R., Parliamentary socialism: a study in the politics of Labour, $2^{\text {nd }}$ rev. ed., Merlin Press, London 2009.

Millward R., The 1940 s nationalization in Britain. Means to an end or the means of production, „The Economic History Review” 1997, Vol. 50, Nr 2.

Mitchell A., Revolution in Bavaria, 1918-1919: the Eisner Regime and the Soviet Republic, Princeton University Press, Princeton, N.J. 1965.

Morabito M., Bourmand D., Historia konstytucyjna i polityczna Francji (1789-1958), tłum. A. Jamróz, Temida 2, Białystok 1996.

Morawski W. [Witold], Wprowadzenie, w: Modernizacja Polski. Struktury, agencje, instytucje, red. W. [Witold] Morawski, Wydawnictwa Akademickie i Profesjonalne. Akademia Leona Koźmińskiego, Warszawa 2010.

Morgan K.O., Labour in power, 1945-1951, Clarendon Press, Oxford 1984.

Morrison H., Socialisation and transport: the organisation of socialist industries with particular reference to the London Passenger Transport Bill, Constable \& Co Ltd., London 1933.

Müller W.C., Condemned the success: the 1945 transitional government in Austria, https:// www.prio.org/global/upload/CSCW/Transitional_Governance/Muller.pdf

Napel M., The development of Dutch Christian Democracy, w: Christian democracy in the European Union [1945/1995]. Proceedings of the Leuven Colloquium 15-18 November 1995, Leuven University Press, Leuven 1997.

Nohlen D., Stöver P., Elections in Europe: a data handbook, $15^{\text {th }}$ ed., Nomos, Baden-Baden-Chicago 2010.

Nunes A.B., Bastien C., Valério N., Nationalizations and de-nationalizations in Portugal (19 $9^{\text {th }}$ and $20^{\text {th }}$ Centuries): a historical assessment, Documento de Trabalho, „Working Paper” Nr 22, GHES, Lisboa 2005, https://aguila1.iseg.ulisboa.pt.pdf

Oil and gas in Austria, www.viennabasin.spe.org/aboutus/whatisspevbs/oilandgasinaustria.pdf

Osajda K., Nacjonalizacja i reprywatyzacja, C.H. Beck, Warszawa 2009.

Pathirane L., Blades D., Defining and measuring the public sector: some international comparisons, „Review of Income and Wealth” 1984, Vol. 28, Nr 3. 
Pearson R., Escaping from the state? Historical paths to public and private insurance between the eighteenth and twentieth centuries, X Congreso Internacional de la Associación Española de Historia Ecónomica (AEHE), Carmona, 8-9 September 2011, www.aehe. net/xcongreso/pdf/sesiones/seguros.pdf

Piotrowska-Hochfeld K., Zagadnienia wzrostu gospodarczego Włoch, PWE, Warszawa 1964.

Plessis A., The history of banks in France, www.fbf.fr/en/files/888HK2/History_banks_france_ EN.pdf

Posner M.V., Woolf S.J., Italian public enterprise, Gerald Duckworth \& Co Ltd., London 1967.

Poznański K.Z., Property rights perspective on evolution of communist-type economies, $\mathrm{w}$ : Contructing capitalism. The reemergence of civil society and liberal economy in the post-communist World, red. K.Z. Poznanski, Westview Press, Boulder, Col. 1992.

Prescott W., British conservatism, 1945-1951: adapting to the age of collectivism, March 2015, The University of Adelaide, https:/digital.library.adelaide.edu.au/dspace/bitstream/2440/95244/3/0.pdf

Prost A., Zarys historii Francji w XX wieku, tłum. J. Błońska, Universitas, Kraków 1997.

Pryke R., Public enterprise in practice: the British experience of nationalisation over two decades, MacGibbon \& Kee, London 1971.

Ranieri R., Partners and enemies: the government's decision to nationalise steel 1944-1948, $\mathrm{w}$ : The political economy of nationalisation in Britain, 1920-1950, red. R. Millward, J. Singleton, Cambridge University Press, Cambridge 1995.

Rood L., Nationalisation and indigrenisation in Africa, „The Journal of Modern African Studies" 1976, Vol. 14, Nr 3.

Rotschild K.W., Austria's economic development between two wars, Frederic Muller Ltd., London 1947.

Rowland B.M., Gaullist economic policies: the role of indicative planning, w: Charles de Gaulle's legacy of ideas, red. B.M. Rowland, The Washington Foundation for European Studies, Washington, D.C. 2011.

Rubio M., Oil and economy in Mexico, 1900-1930 s., Universitad Pompeu Fabia, Department of Economics and Business (Barcelona, Spain), www.ecom.upf.edu/docs/papers/downloads/690.pdf

Rydel J., Okupacja Austrii, w: Najnowsza historia świata 1945-1995, t. 1, 1945-1963, red. A. Patek, J. Rydel, J.J. Węc, Wydawnictwo Literackie, Kraków 1997.

Rydel J., Traktat pokojowy z Austrią, w: Najnowsza historia świata 1945-1995, t. 1, 1945-1963, red. A. Patek, J. Rydel, J.J. Węc, Wydawnictwo Literackie, Kraków 1997.

Sadzikowski W., Wielka Brytania, w: W. Sadzikowski, J. Sikorski, A. Wieczorkiewicz, Sektor państwowy w kapitalizmie. Wielka Brytania, Francja, Austria, Włochy, PWN, Warszawa 1971.

Sakkas J., "The Times” and the British intervention in Greece in December 1944, „Balkan Studies" 2012, Vol. 46. 
Sfikas T.D., War and peace in the strategy of the Communist Party of Greece, „Journal of Cold War Studies" 2001, Vol. 3, Nr 3.

Sheard S., A creature of its time: the critical history of the creation of the British NHS, www. michaelquarterly.np.pdf/2011/4-428-41.pdf

Shell K.L., The transformation of Austrian socialism, State University of New York, New York, N.Y. 1962.

Short R.P., The role of public enterprises: an international statistical comparison, w: R.H. Floyd, C.S. Gray, R.P. Short, Public enterprises in the mixed eonomies. Some macroeconomic aspects, International Monetary Fund, Washington, D.C. 1984.

Sikorski J., Austria, w: W. Sadzikowski, J. Sikorski, A. Wieczorkiewicz, Sektor państwowy w kapitalizmie. Wielka Brytania, Francja, Austria, Włochy, PWN, Warszawa 1971.

Singleton J., Labour, the Conservatives and nationalisation, w: The political economy of nationalisation in Britain, 1920-1950, red. R. Millward, J. Singleton, Cambridge University Press, Cambridge 1995.

Skidelsky R., Keynes. Powrót mistrza, tłum. T. Krzyżanowski, M. Sutowski, Wydawnictwo Krytyki Politycznej, Warszawa 2012.

Sloman P., The Liberal Party and the economy, Oxford University Press, Oxford 2015.

Smith G., Życie polityczne w Europie Zachodniej, tłum. L. Dorn, Puls, Londyn 1992.

Steininger R., Austria, Germany and the cold war. From the Anschluss to the State Treaty 1938-1955, Berghahn Books, New York-Oxford 2008.

Stelmachowski A., Zdziennicki B., Prawo rolne, PWN, Warszawa 1980.

Stiefel D., Fifty years of state-owned industry in Austria, 1946-1996, w: The rise and fall of state-owned enterprise in the western world, red. P. Toninelli, Cambridge University Press, Cambridge 2000.

Sztaba S., Kapitalizm amerykański, w: Oblicza kapitalizmu, red. P. Jachowicz, S. Sztaba, Oficyna Wydawnicza SGH, Warszawa 2011.

The nationalisation of Austria's basic industries [The Federal Ministry of Transport and Nationalised Undertakings], „Annals of Collective Economy” 1952, Vol. 23, Nr 1.

The Programme of the M.R.P. [23 ${ }^{\text {rd }}$ March 1946], www.archive.thetablet.co.uk./article/23rd-march-1946/6/Programme-of-the-mrp.pdf

Therborn G., Drogi do nowoczesnej Europy. Społeczeństwa europejskie w latach 1945-2000, tłum. Z. Pucek, Wydawnictwo Naukowe PWN, Warszawa-Kraków 1998.

Thorpe A., A history of the British Labour Party, $3^{\text {rd }}$ ed., Palgrave MacMillan, London 2008.

Timashoff N.S., Nationalization in Europe and the catholic social doctrine, „The American Catholic Sociological Review" 1947, Vol. 8, Nr 2.

Tivey L., Nationalization of British industry, rev. ed., Jonathan Cape Ltd., London 1973.

Tomlinson J., Democratic socialism and economic policy: the Attlee years, 1945-1951, Cambridge University Press, Cambridge 1997. 
Toninelli J., From private to public to private again: a long-term perspective on nationalization, „Análise Social” 2008, Vol. 43, Nr 4.

Tookey M.E., The Labour Party and nationalisation from Attlee to Wilson, 1945-1968: beyond the commanding heights, Durham University, December 2000, www.etheses.dur. ac.uk./4552/1/4522_1986.pdf

Tōyama Y., The origins of nationalization in Britain (III), „Otemon Economic Studies” 1975, Vol. 8.

Toye R., The Labour Party and the planned economy, 1931-1951, Boydell Press, Rochester, N.Y. 2003.

Unger B., Heitzmann K., The Austrian „AlpenModel” - back to Bismarck?, www.2.econ. uu.nl/users/unger/publications/ungerheitzmann11.pdf

Walicki A., Marksizm i skok do królestwa wolności. Dzieje komunistycznej utopii, Wydawnictwo Naukowe PWN, Warszawa 1996.

Wädekin K.E., Agrarian policies in communist Europe: a critical introduction (Studies in European \& Soviet Russian agrarian policy), Martinus Nijhoff Publishers. Allanheld, Osmun \& Co. Publishers Inc., The Hague-London 1982.

Webster C., The National Health Service. A political history, Oxford University Press, Oxford-New York 1998.

Wengenroth U., The rise and fall of state-owned enterprise in Germany, w: The rise and fall of state-owned enterprise in the western world, red. P. Toninelli, Cambridge University Press, Cambridge 2000.

Wereszycki H., Historia Austrii, Zakład Narodowy im. Ossolińskich, Wrocław-Warszawa-Kraków-Gdańsk 1972.

Wieczorkiewicz A., Francja, w: W. Sadzikowski, J. Sikorski, A. Wieczorkiewicz, Sektor państwowy w kapitalizmie. Wielka Brytania, Francja, Austria, Włochy, PWN, Warszawa 1971.

Williams Ch., Charles de Gaulle. Ostatni wielki Francuz, tłum. A. Chajewski, Amber, Warszawa 2007.

Woloch I., Left, right and centre: the MRP and the post-war moment, „French History” 2007, Vol. 21, Nr 1.

Zariski R., Problems and prospects of democrtaic socialism in France and Italy, „The Journal of Politics" 1956, Vol. 18, Nr 2.

Zawadzki J., Kapitalizm współczesny. Szkice ekonomiczne, wyd. 2 zm., PWE, Warszawa 1967. 


\section{Nationalizations in Western Europe in the second half of the 1940s}

Nationalizations in the Austrian, French and British economies in the second half of the 1940s are the subject of this paper. The author analyses how they were conducted, what sectors and enterprises were affected and what was their context (earlier and later nationalizations), particularly political. The main conclusion of the text stresses that time frame and solutions adopted during nationalizations were primarily caused by the local verities and evolutions of governing systems. The author also stresses the need to separate nationalization from other forms of public sector expansions.

Keywords: nationalization, 1940 s, Western Europe (Austria, France, UK)

\section{Nationalisations en Europe doused dams la deuxième moitié des années 40 du XXème siècle}

Le sujet de l'article sont les nationalisations introduites dans la deuxième moitie des années 40 du XXème siècle dans les économies de l'Autriche, de la France et de la Grande Bretagne. L'auteur analyse leur déroulement, leur extension et leurs conditions dans le cadre de l'histoire précédente et postérieure des nationalisations et aussi des transformations politiques en Europe d'Ouest dans les premières années après la IIème Guerre Mondiale. La conclusion principale consiste à constater que c'est avant tout la spécifique et l'évolution des systèmes locaux de gouvernement qui a décidé de l'exécution, de la forme et de la chronologie des nationalisations en Autriche, en France et en Grande Bretagne. Larticle attire aussi l'attention au besoin de faire la différence entre la nationalisation et d'autres formes de l'augmentation de l'importance du secteur national dans le cadre d'une économie.

Mots-clés: la nationalisation; la seconde moitié des années 40 du XXe siècle; Europe de l'Ouest (Autriche, France, Grande-Bretagne) 


\section{Национализация в Западной Европе в конце 40-х гr. XX века}

Темой статьи являются национализации, проведенные во второй половине 40-х гг. ХХ века в Австрии, Франции и Великобритании. Автор подвергает анализу их ход, масштабы и условия, относясь к прежней и позднейшей истории национализации, а также политические преобразования в Западной Европе в первые годы после Второй мировой войны. Основной вывод заключается в том, что о совершении, форме и хронологии национализаций в Австрии, Франции и Великобритании решали характер и эволюция их систем правления. Статья также указывает на необходимость проведения различия между национализацией и другими формами увеличения государственного сектора в экономике.

Ключевые слова: национализация, вторая половина 40-х годов XX века, Западная Европа (Австрия, Франция, Великобритания) 